Araştırma Makalesi - Research Article

\title{
Örgütsel Bağlılık ve Değişime Direncin Pozitif İş Davranışları, Geri Çekilme Davranışları ve Muhalif İş Davranışları Üzerindeki Etkileri ${ }^{1}$
}

\section{Effects of Organizational Commitment and Resistance to Change on Positive Work Behaviors, Withdrawal Behaviors and Antagonistic Work Behaviors}

\author{
Caner YILMAZ* \\ (D) 0000-0002-1954-4214 \\ Hande ÖZGEN** \\ (iD) 0000-0002-6939-6723 \\ ÖZ
}

$\mathrm{Bu}$ çalışmada örgütsel bağlılığın alt boyutları (duygusal, normatif ve devam bağl1lı̆̆ 1 ) ve değişime direncin, çalışanların işyeri davranışları (pozitif iş davranışları, geri çekilme davranışları ve örgüte yönelik muhalif davranışlar) üzerindeki etkilerinin saptanması amaçlanmıştır. Ayrıca örgütsel bağlılık, değișime direnç ve işyeri davranışlarının demografik özelliklere (cinsiyet, eğitim düzeyi, unvan ve kurumda çalışma süresi) göre farklılaşıp farklılaşmadığı test edilmiştir. Veri toplamada Meyer ve Allen'ın (1997) Örgütsel Bağlılık Ölçeği, Oreg'in (2003) Değişime Direnç Ölçeği ve Lehman ve Simpson'ın (1992) İşyeri Davranışları Ölçeği kullanılmıştır. Araştırmaya Sosyal Güvenlik Kurumu Başkanlığına bağlı Ankara İl Müdürlüklerinde görev yapan 259 kamu çalışanı (115 kadın, 144 erkek) katılmıştır. Bulgular, erkek çalışanların daha fazla pozitif iş davranışları sergilediğini göstermiștir. Eğitim düzeyi düșük olan çalışanların duygusal ve normatif bağlılıklarının, değişime direnç eğilimlerinin daha yüksek olduğu ve daha fazla fiziksel geri çekilme davranışları sergiledikleri tespit edilmiştir. Ayrıca, pozitif iş davranışları üzerinde sadece normatif bağlılığın etkili olduğu, duygusal bağlılığın değişime dirençle birlikte psikolojik geri çekilme davranışını yordadığı, değişime direnç gösteren çalışanların fiziksel geri çekilme ve muhalif iş davranışları sergileyebildikleri saptanmıştır.

Anahtar Sözcükler: Örgütsel bağll1ık, değişime direnç, pozitif iş davranışları, geri çekilme davranışları, muhalif iş davranışları
Sosyal Güvenlik Dergisi / Journal of Social Security

Cilt: 11 Sayı: 1 Yıl: 2021 /Volume: 11 Issue: 1 Year: 2021

ayfa Aralığı: 227-248/ Pages: 227-248

OI: 10.32331/sgd.952593

\section{ABSTRACT}

In this study, it was aimed to determine the effects of organizational commitment sub-dimensions (affective, normative and continuance commitment) and resistance to change on on-the-job behaviors (positive work behaviors, withdrawal behaviors and antagonistic work behaviors). In addition, it was tested whether organizational commitment, resistance to change and on-the-job behaviors differ according to demographic characteristics (gender, education level, title and duration of work in the institution). Meyer and Allen's (1997) Organizational Commitment Scale, Oreg's (2003) Resistance to Change Scale and Lehman and Simpson's (1992) On-the-Job Behaviors Scale were used for gathering data. A total of 259 public employees (115 female, 144 male) working in Ankara Provincial Directorates under the Social Security institution participated in the research. The results revealed that male employees exhibit more positive work behaviors. It has also been observed that employees with low level of education have higher affective and normative commitment, tendency to resist to change and exhibit more physical withdrawal behaviors. The results also showed that only normative commitment predicts positive work behaviors. Affective commitment together with resistance to change predicts psychological withdrawal behaviors, and employees who are resistant to change may exhibit physical withdrawal behaviors and antagonistic work behaviors.

Keywords: Organizational commitment, resistance to change, positive work behaviors, withdrawal behaviors, antagonistic work behaviors

Önerilen atıf şekli: Yılmaz, C. ve Özgen, H. (2021). Örgütsel Bağlılık ve Değişime Direncin Pozitif İş Davranışları, Geri Çekilme Davranışları ve Muhalif İş Davranışları Üzerindeki Etkileri. Sosyal Güvenlik Dergisi (Journal of Social Security). 11(1). 227-248

- Geliş Tarihi/Received: 17/02/2021 • Güncelleme Tarihi/Revised: 07/06/2021 • Kabul Tarihi/Accepted: 14/06/2021

\footnotetext{
${ }^{1}$ Bu çalışma Caner Yılmaz'ın, Dr. Öğretim Üyesi Hande Özgen danışmanlığında Türkiye ve Orta Doğu Amme İdaresi Enstitüsünde 08.05.2018 tarihinde kabul edilen "Örgütsel Bağlılık, Değişime Direnç Algısı ve İş Davranışlarının İncelenmesi: Ankara Sosyal Güvenlik İl Müdürlüğü Örneği” başlıklı yüksek lisans tezinden üretilmiştir.

* Doktora Öğrencisi, Ankara Hacı Bayram Veli Üniversitesi, Sigortacılık Bölümü, y.caner@hbv.edu.tr

** Dr. Öğr. Üyesi, Ankara Yıldırım Beyazıt Üniversitesi, İşletme Bölümü, Yönetim ve Organizasyon Anabilim Dalı, hozgen@ybu.edu.tr
} 


\section{GíRIŞ}

Örgütlerin sürekli gelişen çevresel şartlara uyum sağlayabilmeleri, rekabet edebilir olmaları için örgütsel değişimler önemli görülmektedir (Elias, 2009; Iverson, 1996). Kotter ve Schlesinger (1979), çoğu örgütün her sene ufak değişikliklere gittiğini dört, beş senede bir de çok daha önemli değişikliklere ihtiyaç duyduklarını belirtmişlerdir. Değişim girişimi örgütlerin varlıklarını devam ettirmeleri için gerekli görülmekle birlikte, çalışanlar için zorlu bir süreç olarak düşünülmektedir (Paolillo, Platania, Magnano ve Ramaci, 2015). Kotter (1995), bu sürecin zorlu olmasının nedenlerinin değişim vizyonunu belirlemede görülen eksiklikler, planlamanın iyi yapılamaması, örgüt yöneticilerinin bu süreçteki desteklerinin yetersiz olması, iletişim eksiklikleri ve değişimin gerekliliğinin yeterince anlaşılamaması gibi faktörlerden kaynaklandığını belirtmiştir. Örgütsel değişim, işin yapılış şeklinde, örgütsel yapıda, kullanılan teknolojide, çalışanların davranış biçimlerinde (Gonçalves ve da Silva Gonçalves, 2012; Iverson, 1996) görülen revizyon ihtiyacına ilişkin başlatılan bir süreçtir. Çalışanlar açısından düşünüldüğünde en küçük değişimden en majör olanına kadar, çalışanların konfor alanlarından çıkmalarına neden olmaktadır.

Değişim, karşı konulması güç ve doğal bir süreç olmakla birlikte çalışanların değişim karşısında gösterecekleri tepkileri tahmin etmek kolay değildir (Gonçalves ve da Silva Gonçalves, 2012). Bu tepkiler olumlu ya da olumsuz olarak farklı biçimlerde görülebilmektedir. Değişimle baş edebilen çalışanlar örgüte katkı sağlama, rol ötesi davranışlar sergilemeye isteklilik (Bellou, 2008) gibi olumlu tepkiler gösterirken, değişim sürecinde kendilerini güvende hissetmeyen, mevcut durumlarını korumak isteyen çalışanlar (Pakdel, 2016) olumsuz tepkiler göstereceklerdir. Okumus ve Hemmington'a (1998) göre değişim ne kadar radikal olursa değişime gösterilen tepkiler de o derece önemli ve sert olacaktır. Bu tür olumsuz tepkiler değişim literatüründe genel olarak değişime direnç olarak kavramlaştırılmıştır. Değişim sürecinin dirençle karşılık bulması düşük moral, performansta azalış (Chiang, 2010) gibi olumsuz sonuçlara neden olmaktadır. Bunu destekler biçimde Falkenburg ve Schyns'e (2007) göre çalışan performansını açıklamada kullanılacak yaklaşımlardan biri de geri çekilme davranışlarını incelemektir.

Literatürde değişimin başarılı olmasını sağlayan unsurlardan birinin çalışanların örgütlerine bağlılık düzeyleri olduğunu belirten çalışmalar olduğu görülmektedir (ör. Klein ve Sorra, 1996; McKay, Kuntz ve Naswall, 2013; Peccei, Giangreco ve Sebastiano, 2011) Ayrica örgütsel bağlılığın geri çekilme davranışlarını azalttığ 1 , daha pozitif iş sonuçlarına neden olduğu da saptanmıştır (ör. Hanisch ve Hulin, 1991; Meyer, Stanley, Hersovitch ve Topolnytsky, 2002).

$\mathrm{Bu}$ çalışmada çalışanların örgütsel bağlılık düzeylerinin ve değişim karşısında gösterdikleri direncin işyeri davranışlarına etkileri incelenmiştir. İşyeri davranışları olarak Lehman ve Simpson'ın (1992) modeli kullanılmıştır. Bu modelde işyeri davranışları pozitif iş davranışları, psikolojik ve fiziksel geri çekilme davranışları ve muhalif iş davranışları olarak dört kategoride ele alınmıştır (Lehman ve Simpson, 1992). İlgili literatür incelendiğinde değişime direncin, örgütsel sinizm (Grama ve Todericiu, 2016), liderin süreçteki rolü (Mangundjaya, Utoyo, Wulandari, 2015), örgütsel güven (Örücü ve Kambur, 2019), stres (Tavakoli, 2010), sivil erdem ve işten ayrılma niyeti (Bellou, 2008), algılanan örgütsel destek (Ming-Chu ve Meng-Hsiu, 2015) ile ilişkilendirildiği görülmüştür. Bağlılık ve değişime direnç çalışmalarında ise öz-yeterlik, duygusal zekâ (Sasikala ve Anthonyraj, 2015), iletişim ve değişime hazır oluş (McKay vd., 2013), örgütsel adalet (Ayden ve Yılmaz, 2018; Foster, 2010), kişi-örgüt uyumu (Meyer, Hecht, Gill ve Toplonytsky, 2010) değişkenleri incelenmiştir. Literatürde örgütsel bağlılığın geri çekilme davranışları (Somers, 2009), negatif davranışlar (Qazi, Naseer ve Syed, 2019) ve üretkenlik karşıtı davranışlarla (Baysal, 
Mısırdalı Yangil ve Sevim, 2020) ilişkisinin ele alındığı ancak bütüncül bakış açısıyla örgütsel bağlılık ve değişime direncin pozitif (pozitif iş davranışları) ve negatif (psikolojik ve fiziksel geri çekilme ile muhalif iş davranışları) davranışlar üzerindeki etkilerinin aynı örneklem grubunda çalışılmadığı görülmüştür.

Çalışmada olumlu ve olumsuz işyeri davranışları üzerinde bağlılık ve değişime direncin etkilerinin incelenmesinin değişime direnç gösteren çalışanların olumlu veya olumsuz olası tepkilerini ortaya koymak açısından önemli olduğu düşünülmektedir. Ayrıca çalışanların demografik özelliklerine göre örgütsel bağlılık ve alt boyutları, değişime direnç ve işyeri davranışları açısından fark olup olmadığı, fark çıkan ortalamaların hangi gruplar arasında olduğu da çalışma kapsamında incelenmiştir.

\section{I- KAVRAMSAL ÇERÇEVE}

Örgütsel bağlılığın literatürde farklı şekillerde ele alındığı ve ölçüldüğü görülmektedir. Örneğin Becker (1960), çalışanın örgüte yaptığı yatırım ve bundan algıladığı kazancın örgüt üyeliğini devam ettirmede anahtar rol olduğunu belirtmiştir. Kavramsallaştırmaya ilişkin ilk çalışmalarda bağlılığın duygusal boyutuna vurgu yapan yaklaşımlar da öne çıkmaktadır. Kanter (1968: 507), kavramı "gruba duygusal bağlanma" olarak ele almıştır. Buchanan (1974: 533) ise "örgütün amaç ve değerlerine duygusal bağlanma" olarak tanımlamış ve kimlikle özdeşleşme, katılım ve sadakat olmak üzere bağlılığın üç boyutundan bahsetmiştir. Porter, Steers, Mowday ve Boulian'e (1974: 604) göre örgüte bağlllık "bireyin örgütüyle bütünleşmesi ve katılımı" dır. Porter vd.'nin (1974: 604) yaklaşımında örgütsel bağlılık; "örgütün amaç ve hedeflerini kabul etme", "örgüt yararına çaba sarf etmeye isteklilik” ve "örgüt üyeliğini devam ettirme arzusu” olmak üzere üç faktörle ele alınmaktadır. O’Reilly ve Chatman (1986: 493) ise örgütsel bağl1lığ "kişinin örgütü için hissettiği psikolojik bağlanma" olarak tanımlamışlardır. Örgütsel bağlılığın normatif boyutunun olduğunu öne süren Wiener (1982: 418) bağlılı̆̆ "örgütün ilgi alanlarını karşılamaya yönelik normatif baskılar" olarak ele almış ve çalışanların örgütsel amaçlara ulaşmada kendilerini yükümlü hissetmelerinin etkin olduğunu ifade etmiştir (Wiener, 1982).

Örgütsel bağlılık çalışmalarında sıklıkla kullanılan model Meyer ve Allen'ın (1991) üç bileşenli modelidir. Meyer ve Allen (1984), örgütsel bağlılığı ilk olarak duygusal ve devam bağlılı̆g alt boyutlarıyla ele almışlar; daha sonra Wiener'ın (1982) normatif bağlılık boyutunu da ekleyerek örgütsel bağlılığı üç boyutlu bir yapı olarak değerlendirmişlerdir (Meyer ve Allen, 1991). Duygusal bağlılık boyutu çalışanların örgütleriyle gönül bağı kurmaları, özdeşleşmeleri ve örgütsel faaliyetlere yüksek düzeyde katılımları olarak ele alınmış, devam bağlılığı bileşeni çalışanların örgütten ayrılmalarının getireceği maliyetler nedeniyle örgütte kalmalarının bir fonksiyonu olarak ve normatif bağlılık ise çalışanların örgüte karşı hissettikleri yükümlülükler olarak tanımlanmıştır (Allen ve Meyer, 1990: 1).

Allen ve Meyer'a (1990) göre; duygusal, devam ve normatif bağl1lık örgütsel bağl1lı̆̆ın farklı türleri olmaktan ziyade birbirlerinden ampirik olarak ayrılabilir bileşenler olarak düşünülmelidir. Duygusal ve normatif bağlılık ayrı yapılar olmakla birlikte ampirik olarak benzer sonuçlar vermekte (Allen ve Meyer, 1990; Meyer vd., 2002), duygusal ve devam bağlılığı ise ampirik olarak birbirinden ayrı yapılar olarak düşünülmektedir (Allen ve Meyer, 1990). Dolayısıyla Meyer ve Allen (1991), örgütsel bağlılığa ilişkin sonuçların bağlılığın alt boyutlarına göre yorumlanması gerektiğini belirtmişlerdir. Her bir bağlılık türü ayrı olarak puanlanabilmekte ve her bir boyut çalışanların "bağlılık profillerinin" ortaya çıkarılmasında kullanılabilmektedir (Meyer ve Allen, 2004). Üç boyutun ortak noktası çalışanların örgüt üyeliklerini devam ettirmelerinin altında yatan nedeni ortaya koyabilmesidir. Duygusal bağlılı̆̆ı yüksek çalışanlar örgütte kalmaya istekli, yapabileceklerinin en iyisini yapmak 
isteyen kişilerdir (Allen ve Meyer, 1996). Normatif bağlılı̆̆ı yüksek kişiler, örgüte hissettikleri yükümlülük nedeniyle örgütte kalırken, devam bağlılığı yüksek kişiler örgüt üyeliğini devam ettirmek için diğer iki bağlılık türüne göre en az çabayı gösteren ve işten ayrılmanın getireceği maliyetlerden kaçınmak istedikleri için örgüt üyeliklerini sürdüren kişilerdir (Allen ve Meyer, 1996).

Örgütsel bağlılık ve alt boyutlarının çeşitli iş tutumlarıyla ilişkisini araştıran birçok çalışma bulunmaktadır. $\mathrm{Bu}$ çalışmalarda özellikle duygusal bağlılığın iş sonuçları açısından en olumlu bileşen olduğu ortaya konmuştur (ör. Ariani, 2012; Genevičiūtè-Janonienè ve Endriulaitienè, 2014; Meyer vd., 2002). Normatif bağlılık da duygusal bağlılık kadar güçlü olmamakla birlikte pozitif iş sonuçlarını sağlayabilmektedir (ör. Meyer vd., 2002). Literatürde devam bağlılığının yüksek olmasının ise daha olumsuz iş sonuçlarına neden olduğu ifade edilmektedir (ör. Wasti, 2005).

Bağlılık ile ilişkisi araştırılan değişkenlerden biri de çalışanların örgütsel değişimler karşısındaki dirençleridir. Örgütsel değişimler birçok zaman çalışanların direnç göstermelerine neden olmaktadır (Chreim, 2008; Iverson, 1996). Değişime direnç kavramı ilk olarak Coch ve French (1948) tarafından ortaya atılmıştır. Değişime direnç "örgütsel değişim hedeflerini engelleyen tutum ve davranışlara bağlılık" olarak tanımlanmaktadır (Chawla ve Kelloway, 2004: 485). Tavakoli (2010: 1795) ise kavramı "sıkıntı düzeyini azaltmaya yönelik davranışsal tepkiler" olarak tanımlamaktadır. Armenakis ve Bedeian (1999), değişim uygulamalarının başarılı olmasında bağlılığın önemli bir değişken olduğunu belirtmişler, Genevičiūtè-Janonienè ve Endriulaitienè (2014) ise, devam bağlılığının değişime direncin önemli bir yordayıcısı olduğunu söylemişlerdir. Sasikala ve Anthonyraj (2015), yaptıkları çalışmada duygusal ve normatif bağlılık ile değişime direnç arasında negatif ilişki olduğunu saptamışlardır. Aynı çalışmada devam bağlılığı ile değişime direnç arasında ise anlamlı ilişki bulunmamıştır. Peccei vd. (2011), örgütsel bağlılığın değişime direncin önemli bir yordayıcısı olduğunu ifade etmişler, örgütsel bağlılık ve değişime direnç ilişkisinde değişime karşı tutumların kısmi aracılık etkisini saptamışlardır. Buna göre; örgütsel bağl1lık değişime karşı tutumlarla pozitif, değişime direnç ile negatif ilişkilidir.

Giangreco ve Peccei'nin (2005) modeline göre; değişime direnç iki önemli faktörün fonksiyonu olarak ortaya çıkmaktadır. Bu faktörler; değişimin algılanan faydaları ve çalışanların değişime katılımıdır. Değişimin algılanan faydası fazla olduğunda, çalışanların değişime karşı tutumları daha olumlu olurken, değişime dirençleri de azalır (Giangreco ve Peccei, 2005).

Meyer vd. (2010), örgütsel değişim sürecinde kişi-örgüt uyumu ve örgütsel bağlılık değişkenlerini inceledikleri boylamsal çalışmalarında hem değişimin ilk aşamalarında hem de değişim sonrası dönemde kişi-örgüt uyumu sağlanmışsa çalışanların bağlılıklarının ve örgüt üyeliklerini devam ettirme eğilimlerinin yüksek olacağını bulmuşlardır. McKay vd. (2013), değişim sürecinde örgütsel iletişimin, çalışanları değişim sürecine dahil etmenin ve çalışanların duygusal bağlılıklarının değişime direnci azalttığını, duygusal bağlılığın değişime hazır oluşla pozitif ilişkili olduğunu saptamışlardır. Değişim sürecine katılım, çalışanların değişimin bir parçası olduklarını hissetmelerine dolayısıyla değişim kaynaklı kaygılarının azalmasına katkı sağlayarak değişime direnci azaltmaktadır (Peccei vd., 2011).

Literatürde değişime direncin bilişsel, duyuşsal ve davranışsal boyutlarından bahsedilmektedir (ör. Piderit, 2000; Smollan, 2006). Duyuşsal bileşen çalışanların değişim karşısında nasıl hissettiklerini, bilişsel bileşen çalışanların değişim karşısındaki düşüncelerini ve davranışsal bileşen ise çalışanların değişime tepki olarak ortaya koydukları eylem ve hareketlerini kapsamaktadır (Piderit, 2000). Bu davranışlar örgütlerde açık (ör. sabotajlar, sesli karşı çıkışlar, çalışanları kışkırtmak) ya da örtük (ör. çıktıları azaltmak, geri çekilmek) 
olarak görülebilmektedir (Giangreco ve Peccei, 2005; Recardo, 1995). Lines (2005: 20), değişime karşı olumsuz tepkilerin ayak direme, örgütsel sessizlik, işten ayrılma, geri çekilme, sabotajlar ve örgüte ilişkin bilgilerin ifşası olarak görüldüğünü belirtmiştir. Idris, O'Driscoll ve Anderson (2011), çalışanların hissettikleri gerginlik düzeyi ve geri çekilme tepkileri arasındaki ilişkileri inceledikleri çalışmalarında, gerginlik düzeyinin işe gelmeme, işe geç gelme ve işgücü devrinde artışlara neden olabildiğini saptamışlardır. Değişim süreçleri de çalışanlar üzerinde gerginlik yaratan olumsuz durumlar olarak görüldüğü için örgütlerde olumsuz davranışların ortaya çıkmasına neden olabilmektedir.

$\mathrm{Bu}$ çalışmada çalışanların örgütsel bağlılıkları ve değişime dirençlerinin işyeri davranışları üzerindeki etkilerinin incelenmesi amaçlanmıştır. İşyeri davranışları olarak Lehman ve Simpson'ın (1992) modeli doğrultusunda pozitif iş davranışları, psikolojik ve geri çekilme davranışları ile muhalif (düşmanca) iş davranışları ele alınmıştır. Örgütsel bağlılık ve değişime direnç literatürü incelendiğinde bu değişkenlerin daha çok geri çekilme davranışlarıyla ilişkisine bakıldığı, pozitif davranışlar ve muhalif davranışlara ilişkin çalışma sayısının oldukça sınırlı olduğu görülmektedir.

Pozitif iş davranışları, ekstra işler için gönüllü olma, fazla mesai yapma, işi iyileştirmek için değişiklikler yapma, iş geliştirmenin yollarını düşünme ve bunun için müzakerelerde bulunma gibi davranışları kapsar (Lehman ve Simpson, 1992: 312). Meyer vd. (2002), yaptıkları meta-analiz çalışmasında örgütsel bağlılığın alt boyutlarının devamlılık, iş performansı ve örgütsel vatandaşlık davranışı gibi pozitif iş davranışlarıyla ilişkisinde duygusal bağlılığın arzu edilen iş davranışlarıyla en güçlü korelasyona sahip olduğunu, bunu normatif bağlılığın izlediğini, devam bağlılığının ise bu değişkenlerle ilişkisiz ya da negatif ilişkili olduğunu saptamışlardır. Lam ve Liu (2014), örgütsel kimliğin duygusal bağlılık ile pozitif ilişkili olduğunu, örgütsel kimlik ve işten ayrılma niyeti arasında duygusal bağlılığın aracı rolü olduğunu saptamışlardır.

Buradan hareketle duygusal ve normatif bağlılığı yüksek çalışanların değişim karşısında daha pozitif iş davranışları sergileyebilecekleri düşünülebilir. Literatürde psikolojik ve fiziksel olarak ele alınan (Rosse ve Hulin, 1985) geri çekilme davranışları, çalışanların işe ilişkin çabalarını azalttıkları dolayısıyla örgütteki iş akışlarının yavaşlamasına neden olan davranışlar olarak tanımlanmıştır (Erdemli, 2015). Fiziksel geri çekilme davranışları, işten erken ayrılmak, devamsızlık, işgücü devri, mola sürelerini uzun tutmak, işyerinde uyuyakalmak, iş gereçlerini evine götürmek gibi davranışları kapsar (Falkenburg ve Schyns, 2007; Lehman ve Simpson, 1992). Psikolojik geri çekilme ise kişilerin iş çevresinden fizikselin ötesinde ruhsal olarak kaçtıkları bir dizi davranışı tanımlamada kullanılır. $\mathrm{Bu}$ davranışlar, işe gelmemeyi düşünme, mesai saatlerinde iş dışındaki konularla ilgili hayal kurmak, işe ilişkin az çaba göstermek, kendi işini başkalarının yapmasına izin vermek gibi davranışları kapsar (Lehman ve Simpson, 1992: 312). Bazı durumlarda değişim karşısında gösterilen direnç muhalif davranışlar gibi, kendisini alenen değişime karşı konuşma veya değişim girişimlerini baltalama gibi değişim karşıtı davranışların daha aktif formlarında da gösterebilir (Peccei vd., 2011: 188). Muhalif davranışlar ise, çalışma arkadaşlarıyla kavga etmek, yönetime itaatsizlik, dedikodu yaymak, diğerlerinin yanlışlarını rapor etmek gibi davranışları içerir (Lehman ve Simpson, 1992: 312).

Geri çekilme davranışları örgütlerde bir süre sonra tüm ekibi olumsuz etkilemektedir. Eder ve Eisenberger (2008), yakın çalışma grubundaki diğer çalışanların geri çekilme davranışları sergilediğini gören çalışanın da geri çekilme davranışı sergilediğini saptamışlardır. Eder ve Eisenberger'e (2008) göre bu durumu olumluya çevirmenin yolu çalışanların örgütsel destek algılamalarıdır. Örgütleri tarafından desteklendiğini düşünen çalışanlar daha az geri çekilme davranışı sergilemektedirler. Ming-Chu ve Meng-Hsiu (2015) algılanan örgütsel destek ve 
değişime direnç ilişkisini test ettikleri çalışmalarında değişime hazır oluşun aracı rolünü saptamışlardır. Buna göre; çalışanlar örgütsel destek algılandıklarında ve değişime yeteri kadar hazır hissettiklerinde değişime dirençleri azalmaktadır. Örgütsel değişim süreçlerinde algılanan örgüt destek çalışan bağlılığını da artırmaktadır (Herscovitch ve Meyer, 2002). Araştırmalar duygusal ve normatif bağlılığın geri çekilme davranışları da dahil olmak üzere iş davranışlarını pozitif yönde etkilediğini, buna karşın devam bağlılığının ise bu tür davranışlarla düşük ilişki gösterdiği ya da ilişkili olmadığı yönündedir. (Luchak ve Gellatly, 2007; Meyer vd., 2002). Örgüte bağlı çalışanların geri çekilme davranışlarıyla daha az ilişkili olacakları düşünülmektedir (Clegg, 1983; Genevičiūtė-Janonienè ve Endriulaitienė, 2014; Lam ve Liu, 2014).

Wasti (2005), örgüte bağlı olmayan çalışanların arzu edilmeyen iş davranışlarını en çok gösteren grup olduğunu, en yüksek geri çekilme ve işten ayrılma niyeti taşıyanların ise örgüte bağlı olmayan grup olduğunu belirtmiştir. Yüksek bağlılık gösteren grup ise diğer gruplarla karşılaştırıldığında geri çekilme davranışlarını en az gösteren ve en az işten ayrılma niyeti taşıyan gruptur (Wasti, 2005). Somers (2009) çalışmasında duygusal, normatif ve devam bağlılığının geri çekilme davranışlarına (devamsızlık, işe geç gelme) etkisini incelemiş ve en olumlu davranışların duygusal-normatif bağlılığı yüksek gruplarda olduğunu saptamıştır. Duygusal bağlılığı düşük olan çalışanların gönüllü devamsızlık yapma, işten ayrılma niyeti taşıma ve düşük performans sergileme eğilimleri daha fazladır (Luchak ve Gellatly, 2007). Meyer vd. (2002), örgütsel bağlılık alt boyutlarının öncül ve sonuçlarına ilişkin yaptıkları meta-analiz çalışmasında üç alt boyutun da geri çekilme bilişi, işten ayrılma niyeti, işgücü devri ile negatif ilişkili olduğunu saptamışlardır. İşe devamsızlık duygusal bağlılık ile negatif, normatif ve devam bağlılığı ile pozitif ilişkilidir.

Örgütsel bağlılık ve değişime direnç değişkenlerinin demografik özelliklere göre farklılaşıp farklılaşmadığını inceleyen çalışmalar da vardır. Pakdel (2006), eğitim düzeyi arttıkça çalışanların değişimi daha olumlu algıladıklarını bulmuştur. Rosenblatt, Talmud ve Ruvio (1999), kadınların örgütsel bağlılık düzeylerinin erkeklerden daha yüksek olduğunu saptamışlar, değişime direnç içinse cinsiyetler arası fark tespit etmemişlerdir. GenevičiūtèJanonienè ve Endriulaitienė (2014), kadınların duygusal ve normatif bağlılıklarının erkeklerden daha yüksek olduğunu, erkeklerin ise kadınlara göre daha fazla değişime direnç gösterdiklerini, geri çekilme davranışları sergilediklerini ve işten ayrılma niyeti taşıdıklarını bulmuşlardır. Alas (2009) ise, kadınların bağlılıklarının daha yüksek olduğunu, lisans eğitimine sahip çalışanların örgütsel bağlılıklarının daha yüksek olduğunu belirtmiştir.

Ele alınan kavramsal çerçeveden hareketle araştırmada aşağıdaki sorulara yanıt aranmıştır.

AS1. Çalışanların örgütsel bağlılık, değişime direnç ve işyeri davranışları demografik özelliklerine (cinsiyet, eğitim düzeyi, pozisyon ve kurumda çalışma süresi) göre anlamlı olarak farklılaşmakta mıdır?

AS2: Örgütsel bağlılık (duygusal, normatif ve devam alt boyutları) ve değişime direnç, pozitif iş davranışlarını anlamlı olarak yordamakta mıdır?

AS3: Örgütsel bağlılık (duygusal, normatif ve devam alt boyutları) ve değişime direnç, psikolojik ve fiziksel geri çekilme davranışlarını anlamlı olarak yordamakta mıdır?

AS4: Örgütsel bağlılık (duygusal, normatif ve devam alt boyutları) ve değişime direnç, muhalif iş davranışlarını anlamlı olarak yordamakta mıdır? 


\section{A-Yöntem}

\section{i) Araştırma Modeli}

Örgütsel bağlılık ve değişime direnç değişkenlerinin işyeri davranışları olarak ele alınan pozitif iş davranışları, geri çekilme davranışları ve muhalif davranışları yordama düzeylerinin incelendiği bu araştırma ilişkisel tarama modelinde (bk. Karasar, 2015) tasarlanmıştır.

\section{ii) Örneklem Grubu ve İşlem}

Araştırma, Sosyal Güvenlik Kurumu Başkanlığına bağlı Ankara İl Müdürlüklerinde görev yapan kamu personeli üzerinde yürütülmüştür. Gerekli yazılı izinler alındıktan sonra Ocak 2017-Temmuz 2017 tarihleri arasında ölçekler kolayda örnekleme yöntemiyle araştırmaya katılmaya istekli katılımcılara yüz yüze uygulanmıştır. 285 katılımcı tarafından yanıtlanan ölçme aracının 10 tanesi eksik doldurulduğu için geçersiz sayılmıştır. 275 katılımcıdan elde edilen veriler üzerinde uç değerleri saptamaya yönelik mahalanobis uzaklığı hesaplanmış, skoru 9.49'dan yüksek olan 16 kişi veri setinden çıkarılmıştır. Analizler 259 kamu personelinden (115 kadın, 144 erkek) elde edilen veriler üzerinde gerçekleştirilmiştir. Katılımcıların \%65,3'ünün eğitim düzeyi lisans ve lisans üstüdür. 21 katılımcı müdür ve müdür yardımcısı, 29 kişi şef, 113 kişi veri hazırlama ve kontrol işletmeni (VHKİ), 50 kişi icra memuru ve 46 kişi denetmen kadrolarında görev yapmaktadır. Katılımcıların \%53,7'si 13 yıldan uzun süredir kurumda görev yaptıklarını belirtmişlerdir.

\section{B- Ölçekler}

\section{i) Örgütsel Bağlılık Ölçeği}

Çalışmada, Meyer ve Allen (1997) tarafından geliştirilen Örgütsel Bağlılık Ölçeğinin Arıkan (2011) tarafından standardize edilen versiyonu kullanılmıştır. Ölçek, örgütsel bağlılığı duygusal bağlılık, devam bağlılığı ve normatif bağlılık olmak üzere üç boyutta açıklamaktadır. Duygusal bağlılık 9 madde, devam bağlılığı 9 madde ve normatif bağlılık 14 madde olmak üzere ölçek toplam 32 maddeden oluşmaktadır. Cevap kategorileri 5'li Likert (1= hiç katılmıyorum; 5= tamamen katılıyorum) olarak yapılandırılmıştır. Ölçekten alınan yüksek puan örgütsel bağlılığın yüksekliğine işaret etmektedir. Örnek maddeler; duygusal bağlılık için "Meslek hayatımın kalan kısmını bu kurumda geçirmek beni çok mutlu eder.", devam bağlılığı için "İstesem de çalıştığım kurumdan şu anda ayrılmak benim için çok zor olurdu." normatif bağlılık için "Bu kurumdan ayrılıp burada kurduğum kişisel ilişkileri bozmam doğru olmaz." olarak verilebilir. Bu çalışmada Cronbach alfa katsayısı tüm ölçek için 0.93 , duygusal bağlılık alt boyutu için 0.83 , devam bağl1lığ 1 alt boyutu için 0.77 , normatif bağlılık alt boyutu için 0.88 hesaplanmıştır.

\section{ii) Değişime Direnç Ölçeği}

Oreg (2003) tarafından geliştirilen Değişime Direnç Ölçeğinin Altındiş ve Saylı (2011) tarafindan standardize edilen ve tek boyut olarak raporlanan 20 maddelik versiyonu kullanılmıştır. Cevap kategorileri 5'li Likert ( $1=$ hiç katılmıyorum; 5= tamamen katılıyorum) olarak yapılandırılmıştır. Ölçekten yüksek puan almak çalışanların değişim karşısında gösterdikleri direncin fazlalığına işaret etmektedir. Örnek maddeler; "İşler yapılan planlara göre gitmediğinde strese girerim.", "Değişim süreci bende güvensizlik hissi oluşturur." olarak verilebilir. Bu çalışmada ölçeğin Cronbach alfa katsayısı 0.84 hesaplanmıştır.

\section{iii) İşyeri Davranışları Ölçeği}

Lehman ve Simpson (1992) tarafından geliştirilen ölçek birbirinden bağımsız 4 ölçek (kategori) ve toplam 22 maddeden oluşmaktadır. Bu ölçekler; pozitif iş davranışları, 
psikolojik geri çekilme davranışları, fiziksel geri çekilme davranışları ve muhalif iş davranışlarıdır. Cevap kategorileri 5'li Likert $(1=$ hiç katılmıyorum; 5= tamamen katılıyorum) olarak yapılandırılmıştır. Pozitif iş davranışları 5 madde, psikolojik geri çekilme davranışları 8 madde, fiziksel geri çekilme davranışları 4 madde ve muhalif iş davranışları 5 madde ile ölçülmektedir. Pozitif iş davranışları ölçeği için örnek madde "Fazla mesai çalışmak için gönüllü oldum.", psikolojik geri çekilme ölçeği için örnek madde "Işe gelmemeyi düşündüm.”, fiziksel geri çekilme ölçeği için örnek madde "Iş̦ten izin almadan ayrıldım.", muhalif iş davranışları ölçeği için örnek madde "İş arkadaşlarımla kavga ettim." olarak verilebilir.

Ölçeğin standardizasyonu bu çalışmada yazarlar tarafından yapılmıştır. Orijinal ölçek maddeleri makalenin ikinci yazarı tarafindan Türkçeye çevrilmiştir. Çevirisi yapılan maddeler ve maddelerin geri çevirisi üzerinde yönetim ve organizasyon alanı uzmanı iki akademisyen ve anadili İngilizce olan bir akademisyen olmak üzere üç yargıcı tarafından fikir birliğine varıldıktan sonra ölçek maddelerinin anlaşılırlığına ilişkin beş kişi üzerinde ön uygulama yapılmıştır. Bu uygulamada da ölçeğin anlaşılırlığına ilişkin herhangi bir olumsuz dönüş bildirilmemiştir. Lehman ve Simpson (1992), işyeri davranışları ölçeğinin birbirinden bağımsız dört farklı ölçekten (pozitif iş davranışları, psikolojik geri çekilme, fiziksel geri çekilme ve muhalif iş davranışları) oluşan bir yapı olduğunu belirtmişlerdir. Bu nedenle ölçeğin geçerliğini test etmek için her bir ölçek ayrı ayrı faktör analizine tabi tutulmuştur.

Pozitif iş davranışları ölçeği için öncelikle KMO $(0,74)$ ve Barlett küresellik testi $(214,385$; $p=0.000$ ) sonuçları incelenmiş ve değerlerin faktörleştirme için uygun olduğu (bk. Büyüköztürk, 2012) saptanmıştır. Maddelerin öz değeri 1'in üzerinde olan tek faktör altında toplandığ1 ve bu faktörün ölçeğe ilişkin açıkladığı varyansın \%45,92 olduğu görülmüştür. Maddelerin faktör yükleri ise 0,55 ile 0,77 arasında değişmektedir.

Psikolojik geri çekilme ölçeğinin KMO (0.76) ve Barlett küresellik testi (373,499; p=0,000) sonuçları faktör analizi için uygunluk göstermektedir. Ölçeğin özdeğeri 1'in üzerindeki boyutu, varyansın \%61,78'ini açıklamaktadır. Madde faktör yükleri 0,36 ile 0,77 arasında değişim göstermektedir.

Fiziksel geri çekilme ölçeğinin KMO $(0,80)$ ve Barlett küresellik testi $(461,602 ; p=0,000)$ sonucu verinin faktör analizi için uygun olduğu görülmüştür. Özdeğeri 1'den büyük olan faktör, toplam varyansın \%70,11'ini açıklamaktadır. Madde faktör yüklerinin 0,79 ile 0,88 arasında değiştiği görülmektedir.

Muhalif iş davranışları ölçeğinin KMO (0,61) ve Barlett küresellik testi $(190,838 ; p=0,000)$ faktör analizine uygunluğa işaret etmektedir. Özdeğeri 1'in üzerinde olan faktör, toplam varyansın \%38,31'ini açıklamaktadır. Madde faktör yükleri 0,36 ile 0,80 arasında değişim göstermektedir.

İşyeri davranışları ölçeğinin dört faktörü için yapılan faktör analizi sonuçları, her dört ölçeğin de açıkladıkları varyansın \%30'un üzerinde olması ve ölçeklerin madde faktör yüklerinin 0,30'dan yüksek bulunması nedeniyle (bk. Büyüköztürk, 2012) ölçeğin Türkçe formunun geçerli bir ölçüm aracı olduğunu göstermektedir.

Ölçeklerin güvenirliği Cronbach alfa katsayısı ile hesaplanmıştır. Cronbach alfa katsayısı pozitif iş davranışları için 0,69 psikolojik geri çekilme davranışları için 0,68 fiziksel geri çekilme davranışları için 0,85 muhalif iş davranışları için 0,54 olarak bulunmuştur. Pozitif iş davranışları, psikolojik geri çekilme ve muhalif iş davranışlarına ilişkin güvenirlik katsayıları 0.70 'ten küçük olmasına karşın madde sayıları az olan ölçeklerde kabul edilebilir düzeyde olduğu belirtilmektedir (George ve Mallery, 2003; akt. Kılıç, 2016: 48). 


\section{C- Bulgular}

Hipotez testlerine ilişkin analizlerden önce veri setinde "doğrusallık" ve "normallik" varsayımlarının karşılanmasını güçleştiren uç değerlerin olup olmadığı mahalanobis uzaklığı hesaplanarak kontrol edilmiş (bk. Büyüköztürk, 2012), uç değerler veri setinden çıkarılmıştır. Hesaplanan basıklık ve çarpıklık değerleri veri setinin normal dağıldığına işaret etmektedir.

AS1. Çalışanların örgütsel bağlılık, değişime direnç ve işyeri davranışları demografik özelliklerine (cinsiyet, eğitim düzeyi, pozisyon ve kurumda çalışma süresi) göre farklılaşmakta mıdır?

AS1'i test etmek için bağımsız gruplar için $t$-testi ve tek yönlü varyans analizleri (ANOVA) yapılmıştır. Cinsiyete ilişkin $t$-testi sonuçları Tablo 1'de verilmiştir. $t$-testi sonuçlarına göre cinsiyete ilişkin anlamlı fark sadece pozitif iş davranışı değişkeninde saptanmıştır. Buna göre; erkek çalışanlar $(\bar{X}=4.02)$ kadın çalışanlara $(\bar{X}=3.86)$ göre daha fazla pozitif iş davranışı sergilemektedirler.

Tablo 1. Örgütsel Bağlılık, Değişime Direnç ve İşyeri Davranışları ile Cinsiyete İlişkin t-Testi Sonuçları

\begin{tabular}{|c|c|c|c|c|c|c|}
\hline Değişkenler & & $\mathbf{N}$ & Ort. & $\mathbf{S}$ & $t$ & $p$ \\
\hline \multirow[t]{2}{*}{ Duygusal Bağlılık } & Kadın & 115 & 3.11 & 0.80 & \multirow{2}{*}{1,622} & \multirow{2}{*}{0.106} \\
\hline & Erkek & 144 & 3.26 & 0.74 & & \\
\hline \multirow[t]{2}{*}{ Devam Bağlılığı } & Kadın & 115 & 3.06 & 0.72 & \multirow{2}{*}{0.163} & \multirow{2}{*}{0.871} \\
\hline & Erkek & 144 & 3.03 & 0.72 & & \\
\hline \multirow[t]{2}{*}{ Normatif Bağlıık } & Kadın & 115 & 2.88 & 0.74 & \multirow{2}{*}{1.918} & \multirow{2}{*}{0.056} \\
\hline & Erkek & 144 & 3.06 & 0.75 & & \\
\hline \multirow[t]{2}{*}{ Değişime Direnç } & Kadın & 115 & 2.78 & 0.48 & \multirow{2}{*}{1.291} & \multirow{2}{*}{0.198} \\
\hline & Erkek & 144 & 2.70 & 0.49 & & \\
\hline \multirow[t]{2}{*}{ Pozitif İş Davranışı } & Kadın & 115 & 3.86 & 0.50 & \multirow{2}{*}{2.344} & \multirow{2}{*}{0.020 * } \\
\hline & Erkek & 144 & 4.02 & 0.61 & & \\
\hline \multirow[t]{2}{*}{ Psikolojik Geri Çekilme } & Kadın & 115 & 2.14 & 0.58 & \multirow{2}{*}{0.278} & \multirow{2}{*}{0.781} \\
\hline & Erkek & 144 & 2.16 & 0.57 & & \\
\hline \multirow[t]{2}{*}{ Fiziksel Geri Çekilme } & Kadın & 115 & 1.44 & 0.58 & \multirow{2}{*}{1.139} & \multirow{2}{*}{0.256} \\
\hline & Erkek & 144 & 1.52 & 0.57 & & \\
\hline \multirow[t]{2}{*}{ Muhalif İş Davranışı } & Kadın & 115 & 2.12 & 0.56 & \multirow{2}{*}{0.772} & \multirow{2}{*}{0.441} \\
\hline & Erkek & 144 & 2.18 & 0.58 & & \\
\hline
\end{tabular}

${ }^{*} p<0.05$

Araştırma değişkenlerinin eğitim düzeyi, pozisyon ve kurumda çalışma süresine göre farklılaşıp farklılaşmadığının belirlenmesi için yapılan ANOVA sonuçları Tablo 2, 3 ve 4'te verilmiştir.

Tablo 2'de yer alan analiz sonuçları, çalışanların örgütsel bağlılık düzeyleri arasında eğitim düzeyleri açısından anlamlı fark olduğunu göstermektedir $\left[F_{(2,256)}=5.316, p=0.005\right]$. Fark çıkan ortalamaların kaynağını tespit etmek için yapılan LSD testi sonuçlarına göre; lise mezunları ( $\bar{X}=3.27)$ lisans ve üstü mezunlarına $(\bar{X}=2.96)$ göre örgütsel bağlılıkları daha yüksek olan gruptur. Benzer bulgu örgütsel bağlılığın bir alt boyutu olan duygusal bağlılık için de geçerlidir $\left[F_{(2,256)}=3.185, p=0,043\right]$. LSD testi sonuçlarına göre; lise mezunları $(\bar{X}$ = 3.39) lisans ve üstü mezunlarına $(\bar{X}=3.11)$ göre duygusal bağlılıkları yüksek olan gruptur. Diğer bir alt boyut olan normatif bağl1lıkta da eğitim düzeyine göre fark tespit edilmiştir $\left[F_{(2,}\right.$ $\left.{ }_{256)}=7.271, p=0,001\right]$. Farkın kaynağını tespit etmek için yapılan LSD testi sonuçları lise $(\bar{X}=3.26)$ ve ön lisans mezunlarının $(\bar{X}=3.13)$ normatif bağlllıklarının lisans ve üstü $(\bar{X}=2.86)$ gruba göre daha yüksek olduğunu ortaya koymuştur. Devam bağlılığına ilişkin 
olarak eğitim düzeylerine göre anlamlı bir fark saptanamamıştır. Bu bulgular bize eğitim düzeyi görece düşük olan çalışanların kurumlarına daha bağlı olduklarını göstermektedir.

Tablo 2. Örgütsel Bağlllık, Değişime Direnç ve İşyeri Davranışları ile Eğitim Düzeyine İlişsin ANOVA Sonuçları

\begin{tabular}{|c|c|c|c|c|c|c|c|}
\hline Değişkenler & Gruplar & $\mathbf{N}$ & Ort. & $\mathrm{S}$ & $F$ & $p$ & Fark \\
\hline \multirow{3}{*}{$\begin{array}{l}\text { Örgütsel } \\
\text { bağlılık }\end{array}$} & 1. Lise & 55 & 3.27 & 0.66 & \multirow{3}{*}{5.316} & \multirow{3}{*}{$0.005^{* *}$} & \multirow{3}{*}{$\begin{array}{l}1 \text { ve } 3 \\
\text { arasinda }\end{array}$} \\
\hline & 2. Ön lisans & 35 & 3.18 & 0.63 & & & \\
\hline & 3. Lisans ve üstü & 169 & 2.96 & 0.67 & & & \\
\hline \multirow{3}{*}{$\begin{array}{l}\text { Duygusal } \\
\text { bağlılık }\end{array}$} & 1. Lise & 55 & 3.39 & 0.65 & \multirow{3}{*}{3.185} & \multirow{3}{*}{$0.043^{*}$} & \multirow{3}{*}{$\begin{array}{l}1 \text { ve } 3 \\
\text { arasinda }\end{array}$} \\
\hline & 2. Ön lisans & 35 & 3.29 & 0.64 & & & \\
\hline & 3. Lisans ve üstü & 169 & 3.11 & 0.82 & & & \\
\hline \multirow{3}{*}{$\begin{array}{l}\text { Normatif } \\
\text { bağlılık }\end{array}$} & 1. Lise & 55 & 3.26 & 0.71 & \multirow{3}{*}{7.271} & \multirow{3}{*}{$0.001^{* *}$} & \multirow{3}{*}{$\begin{array}{l}1-2 \text { ve } 3 \\
\text { arasinda }\end{array}$} \\
\hline & 2. Ön lisans & 35 & 3.13 & 0.67 & & & \\
\hline & 3. Lisans ve üstü & 169 & 2.86 & 0.75 & & & \\
\hline \multirow{3}{*}{$\begin{array}{l}\text { Devam } \\
\text { bağlılığı }\end{array}$} & 1. Lise & 55 & 3.15 & 0.80 & \multirow{3}{*}{2.041} & \multirow{3}{*}{0.132} & \\
\hline & 2. Ön lisans & 35 & 3.14 & 0.77 & & & \\
\hline & 3. Lisans ve üstü & 169 & 2.96 & 0.68 & & & \\
\hline \multirow{3}{*}{$\begin{array}{l}\text { Değişime } \\
\text { direnç }\end{array}$} & 1. Lise & 55 & 3.03 & 0.47 & \multirow{3}{*}{16.248} & \multirow{3}{*}{$0.000 * * *$} & \multirow{3}{*}{$\begin{array}{l}1 \text { ve } 2-3 \\
\text { arasinda }\end{array}$} \\
\hline & 2. Ön lisans & 35 & 2.77 & 0.45 & & & \\
\hline & 3. Lisans ve üstü & 169 & 2.63 & 0.45 & & & \\
\hline \multirow{3}{*}{$\begin{array}{l}\text { Pozitif iş } \\
\text { davranıșı }\end{array}$} & 1. Lise & 55 & 3.99 & 0.67 & \multirow{3}{*}{0.209} & \multirow{3}{*}{0.812} & \\
\hline & 2. Ön lisans & 34 & 3.93 & 0.53 & & & \\
\hline & 3. Lisans ve üstü & 169 & 3.94 & 0.55 & & & \\
\hline \multirow{3}{*}{$\begin{array}{l}\text { Psikolojik } \\
\text { çekilme }\end{array}$} & 1. Lise & 55 & 2.27 & 0.64 & \multirow{3}{*}{1.342} & \multirow{3}{*}{0.263} & \\
\hline & 2. Ön lisans & 35 & 2.14 & 0.63 & & & \\
\hline & 3. Lisans ve üstü & 169 & 2.12 & 0.53 & & & \\
\hline \multirow{3}{*}{$\begin{array}{l}\text { Fiziksel } \\
\text { çekilme }\end{array}$} & 1. Lise & 55 & 1.66 & 0.72 & \multirow{3}{*}{3.888} & \multirow{3}{*}{$0.022 *$} & \multirow{3}{*}{$\begin{array}{l}1 \text { ve } 2-3 \\
\text { arasinda }\end{array}$} \\
\hline & 2. Ön lisans & 35 & 1.36 & 0.44 & & & \\
\hline & 3. Lisans ve üstü & 169 & 1.45 & 0.53 & & & \\
\hline \multirow{3}{*}{$\begin{array}{l}\text { Muhalif } \\
\text { davranışlar }\end{array}$} & 1. Lise & 55 & 2.25 & 0.68 & \multirow{3}{*}{1.041} & & \\
\hline & 2. Ön lisans & 135 & 2.15 & 0.65 & & 0.355 & \\
\hline & 3. Lisans ve üstü & 169 & 2.12 & 0.52 & & & \\
\hline
\end{tabular}

Araştırmada ele alınan diğer bir değişken olan çalışanların değişim karşısında gösterdikleri direnç de eğitim düzeyine göre anlamlı olarak farklılaşmaktadır $\left[F_{(2,256)}=\right.$ 16.248, $p=0.000]$. Fark çıkan ortalamaları tespit etmek için yapılan LSD testi sonuçlarına göre; lise mezunları ( $\bar{X}=3.03$ ), ön lisans ( $\bar{X}=2.77)$ ve lisans ve üstü ( $\bar{X}=2.63$ ) eğitim 
seviyesine sahip olan personele göre değişimi daha fazla dirençle karşılamaktadırlar. $\mathrm{Bu}$ bulgu eğitim düzeyi düşük olan çalışanların değişime daha fazla direnç gösterdiklerini ortaya koymaktadır.

İş davranışları olarak ele alınan değişkenlerden sadece fiziksel geri çekilme davranışı eğitim düzeyine göre anlamlı olarak farklılaşmaktadır $\left[F_{(2,256)}=3.888, p=0.022\right]$. LSD testi sonuçları lise mezunlarının $(\bar{X}=1.66)$, ön lisans $(\bar{X}=1.36)$ ve lisans ve üstü $(\bar{X}=1.45)$ eğitim seviyesine sahip olan personele göre daha fazla fiziksel geri çekilme davranışı sergilediklerini ortaya koymaktadır.

Örneklem grubu pozisyonlarına göre müdür/ müdür yardımcısı, şef, veri hazırlama ve kontrol işletmeni (VHKİ), icra memuru ve sosyal güvenlik denetmeni olarak ayrılmıştır. Örgütsel bağlılık ve alt boyutlarının bu kadrolara göre anlamlı olarak farklılaşıp farklılaşmadığını tespit etmek için yapılan ANOVA sonuçlarına göre (Tablo 3) örgütsel bağlılık $\left[F_{(4,254)}=\right.$ $7.263, p=0.000]$, duygusal bağl1lık $\left[F_{(4,254)}=7.570, p=0.000\right]$ ve normatif bağl1lık $\left[F_{(4,254)}\right.$ $=8.780, p=0.000]$ için anlamlı fark olduğu görülmüştür.

Örgütsel bağlılık düzeylerinin hangi pozisyon gruplarına göre farklılaştığını tespit etmek için yapılan LSD testi sonuçlarına göre örgütsel bağlılığı en düşük olan grup icra memurlarıdır. Müdür/ müdür yardımcısı $(\bar{X}=3.37)$, şef $(\bar{X}=3.14)$, denetmen $(\bar{X}=3.11)$ ve VHKİ $(\bar{X}=$ 3.13) kadrolarında çalışan personelin icra memurlarına $(\bar{X}=2.63)$ göre kurumlarına daha bağlı oldukları saptanmıştır. Gruplar arasındaki farka ilişkin benzer görünüm duygusal bağlılık ve normatif bağlılık için de geçerlidir. Duygusal bağlılık pozisyona göre anlamlı olarak farklılaşmaktadır $\left[F_{(4,254)}=7.570, p=0.000\right]$. Tukey HSD testi sonuçlarına göre; müdür/ müdür yardımcısı ( $\bar{X}=3.59)$, denetmen $(\bar{X}=3.39)$, şef $(\bar{X}=3.33)$ ve VHKİ $(\bar{X}=$ 3.21) kadrolarında çalışan personelin icra memurlarına $(\bar{X}=2.73)$ göre duygusal bağlılıkları daha yüksektir. Diğer bir alt boyut olan normatif bağlılık da pozisyona göre anlamlı olarak farklılaşmaktadır $\left[F_{(4,254)}=8.780, p=0.000\right]$. Tukey HSD testi sonuçlarına göre; müdür $(\bar{X}$ $=3.41)$, şef $(\bar{X}=3.05)$, VHKİ $(\bar{X}=3.10)$ ve denetmen $(\bar{X}=2.98)$ kadrolarında çalışan personelin icra memurlarına $(\bar{X}=2.49)$ göre normatif bağlılıkları da daha yüksektir. Devam bağlılı̆̆ı pozisyona göre anlamlı olarak farklılaşmamaktadır.

Çalışanların değişime gösterdikleri direnç de pozisyonlarına göre anlamlı olarak farklılaşmaktadır $\left[F_{(4,254)}=6.844, p=0.000\right]$. LSD testi sonuçlarına göre VHKİ $(\bar{X}=2.89)$ unvanlı personel diğer tüm gruplardan daha fazla değişime direnç göstermektedir.

Çalışmada incelenen işyeri davranışlarından sadece pozitif iş davranışı çalışanların pozisyonlarına göre anlamlı olarak farklılaşmaktadır $\left[F_{(4,253)}=3.465, p=0.009\right]$. LSD testi sonuçlarına göre müdür/ müdür yardımcısı $(\bar{X}=4.18)$ ve şef $(\bar{X}=4.18)$ pozisyonlarında çalışanlar denetmenlerden $(\bar{X}=3.82)$ ve icra memurlarından $(\bar{X}=3.81)$ daha fazla pozitif iş davranışı sergilemektedirler. Bulgulara göre, yönetici kadrosunda çalışanların diğer gruplara göre daha fazla pozitif iş davranışı sergiledikleri söylenebilir. 
Tablo 3. Örgütsel Bağlllık, Değişime Direnç ve Isşyeri Davranışları ile Örgütteki Pozisyona İlişkin ANOVA Sonuçları

\begin{tabular}{|c|c|c|c|c|c|c|c|}
\hline Değişkenler & Gruplar & $\mathbf{N}$ & Ort. & $\mathrm{S}$ & $F$ & $p$ & Fark \\
\hline & 1. Müd./ Müd.Yrd. & 21 & 3.37 & 0.58 & \multirow{5}{*}{7.263} & \multirow{5}{*}{$0.000 * * *$} & \multirow{5}{*}{$\begin{array}{c}1-2-3-5 \text { ve } 4 \\
\text { arasinda }\end{array}$} \\
\hline & 2. Şef & 29 & 3.14 & 0.64 & & & \\
\hline \multirow[t]{3}{*}{ Örgütsel bağlılık } & 3. VHKİ & 113 & 3.13 & 0.67 & & & \\
\hline & 4. İcra Memuru & 50 & 2.63 & 0.68 & & & \\
\hline & 5. SG Denetmeni & 46 & 3.11 & 0.58 & & & \\
\hline \multirow{5}{*}{$\begin{array}{l}\text { Duygusal } \\
\text { bağlılık }\end{array}$} & 1. Müd./ Müd.Yrd. & 21 & 3.59 & 0.70 & \multirow{5}{*}{7.570} & \multirow{5}{*}{$0.000 * * *$} & \multirow{5}{*}{$\begin{array}{c}1-2-3-5 \text { ve } 4 \\
\text { arasinda }\end{array}$} \\
\hline & 2. Şef & 29 & 3.33 & 0.68 & & & \\
\hline & 3. VHKİ & 113 & 3.21 & 0.76 & & & \\
\hline & 4. İcra Memuru & 50 & 2.73 & 0.82 & & & \\
\hline & 5. SG Denetmeni & 46 & 3.39 & 0.60 & & & \\
\hline \multirow{5}{*}{ Normatif bağglılıl } & 1. Müd./ Müd.Yrd. & 21 & 3.41 & 0.71 & \multirow{5}{*}{8.780} & \multirow{5}{*}{$0.000 * * *$} & \multirow{5}{*}{$\begin{array}{c}1-2-3-5 \text { ve } 4 \\
\text { arasinda }\end{array}$} \\
\hline & 2. Şef & 29 & 3.05 & 0.69 & & & \\
\hline & 3. VHKI & 113 & 3.10 & 0.72 & & & \\
\hline & 4. İcra Memuru & 50 & 2.49 & 0.74 & & & \\
\hline & 5. SG Denetmeni & 46 & 2.98 & 0.64 & & & \\
\hline \multirow{5}{*}{ Devam bağlılığı } & 1. Müd./ Müd.Yrd. & 21 & 3.07 & 0.60 & \multirow{5}{*}{2.281} & \multirow{5}{*}{0.061} & \\
\hline & 2. Şef & 29 & 3.09 & 0.79 & & & \\
\hline & 3. VHKİ & 113 & 3.11 & 0.72 & & & \\
\hline & 4. İcra Memuru & 50 & 2.75 & 0.71 & & & \\
\hline & 5. SG Denetmeni & 46 & 3.05 & 0.71 & & & \\
\hline \multirow{5}{*}{ Değişime direnç } & 1. Müd./ Müd.Yrd. & 21 & 2.45 & 0.30 & \multirow{5}{*}{6.844} & \multirow{5}{*}{$0.000 * * *$} & \multirow{5}{*}{$\begin{array}{c}3 \text { ve } 1-2-4-5 \\
\text { arasinda }\end{array}$} \\
\hline & 2. Şef & 29 & 2.66 & 0.57 & & & \\
\hline & 3. VHKİ & 113 & 2.89 & 0.47 & & & \\
\hline & 4. İcra Memuru & 50 & 2.59 & 0.48 & & & \\
\hline & 5. SG Denetmeni & 46 & 2.67 & 0.41 & & & \\
\hline \multirow{5}{*}{$\begin{array}{l}\text { Pozitif iş } \\
\text { davranışı }\end{array}$} & 1. Müd./ Müd.Yrd. & 21 & 4.18 & 0.42 & \multirow{5}{*}{3.465} & \multirow{5}{*}{$0.009 * *$} & \\
\hline & 2. Şef & 29 & 4.18 & 0.51 & & & \\
\hline & 3. VHKİ & 113 & 3.96 & 0.62 & & & $1-2$ ve $4-5$ \\
\hline & 4. İcra Memuru & 49 & 3.81 & 0.49 & & & \\
\hline & 5. SG Denetmeni & 46 & 3.82 & 0.55 & & & \\
\hline & 1. Müd./Müd.Yrd. & 21 & 1.96 & 0.55 & & & \\
\hline & 2. Şef & 29 & 2.02 & 0.59 & & & \\
\hline Psikolojik & 3. VHKİ & 113 & 2.18 & 0.64 & 1.500 & 0.203 & \\
\hline & 4. İcra Memuru & 49 & 2.26 & 0.49 & & & \\
\hline & 5. SG Denetmeni & 46 & 2.15 & 0.43 & & & \\
\hline & 1. Müd./Müd.Yrd. & 21 & 1.43 & 0.38 & & & \\
\hline & 2. Şef & 29 & 1.47 & 0.56 & & & \\
\hline Fiziksel çekilme & 3. VHKİ & 113 & 1.50 & 0.68 & 0.142 & 0.966 & \\
\hline & 4. İcra Memuru & 50 & 1.46 & 0.48 & & & \\
\hline & 5. SG Denetmeni & 46 & 1.52 & 0.48 & & & \\
\hline & 1. Müd./Müd.Yrd. & 21 & 2.20 & 0.49 & & & \\
\hline & 2. Şef & 29 & 2.26 & 0.64 & & & \\
\hline Muhalif & 3. VHKİ & 113 & 2.15 & 0.65 & 0.610 & 0.656 & \\
\hline davranışıar & 4. İcra Memuru & 50 & 2.06 & 0.52 & & & \\
\hline & 5. SG Denetmeni & 46 & 2.17 & 0.39 & & & \\
\hline
\end{tabular}

${ }^{* *} p<0.01,{ }^{* * *} p<0.001$

Kurumda çalışma süresi de diğer bir demografik değişken olarak ele alınmıştır (Tablo 4). Örgütsel bağlılık $\left[F_{(4,254)}=6.401, p=0,000\right]$, duygusal bağl1lık $\left[F_{(4,254)}=4.287, p=0,002\right]$, devam bağlılı̆̆ $\left[F_{(4,254)}=4.873, p=0.001\right]$ ve normatif bağl1lık $\left[F_{(4,254)}=6.405, p=0,000\right]$ değişkenleri çalışma süresine göre anlamlı olarak farklılaşmaktadır. Örgütsel bağlılık için fark çıkan ortalamalara bakıldığında Tukey HSD testi sonuçlarına göre; kurumda çalışma süresi 13-18 yıl arası olan çalışanlar $(\bar{X}=3.34), 19-24$ yıl arası olan çalışanlar $(\bar{X}=3.13)$ 
ve 25 yıl ve üstü çalışma süresine sahip olanlar ( $\bar{X}=3.30)$, kurumda çalışma süresi 1-6 yıl arası $(\bar{X}=2.82)$ olanlara göre kurumlarına daha bağlıdırlar. Benzer farklılık duygusal bağlılık ve normatif bağlılık için de geçerlidir. Devam bağlılığı için anlamlı fark çıkan ortalamaları tespit etmek için yapılan Scheffe testine göre 25 yıl ve üstü çalışanların ve 1318 yıl arası çalışanların devam bağlılıkları 1-6 yıl arası çalışanlardan daha yüksektir.

Çalışanların değişime gösterdikleri direnç de kurumda çalışma süresine göre anlamlı olarak farklılaşmaktadır $\left[F_{(4,254)}=3.542, p=0.008\right]$. Tukey HSD testi sonuçlarına göre anlamlı fark; kurumda 25 yıl ve üstü çalışma süresine sahip çalışanlar $(\bar{X}=2.97)$ ile 1-6 yıl arası çalışanlar $(\bar{X}=2.65)$ ve $7-12$ yıl arası çalışanlar $(\bar{X}=2.63)$ arasındadır. Buna göre kurumda çalışma süresi fazla olan personelin değişime daha fazla direnç gösterdikleri söylenebilir.

İşyeri davranışlarına bakıldığında pozitif iş davranışlarının $\left[F_{(4,253)}=3.403, p=0.010\right]$ ve fiziksel geri çekilme davranışlarının $\left[F_{(4,254)}=2.804, p=0.026\right]$ kurumda çalışma süresine göre anlamlı olarak farklılaştığı görülmektedir. Pozitif iş davranışlarına ilişkin LSD testi sonuçlarına göre; $19-24$ yıl arası çalışanlar $(\bar{X}=4.12)$ ile 25 yıl ve üstü çalışanlar $(\bar{X}=4.03)$, 1-6 yıl arası çalışanlara $(\bar{X}=3.80)$ göre daha fazla pozitif iş davranışı gösterme eğilimindedirler. Fiziksel geri çekilme davranışlarına ilişkin LSD testi sonuçlarına göre ise anlamlı fark 13-18 yıl arası çalışanlar $(\bar{X}=1.70)$ ve 25 yıl ve üstü çalışanlar $(\bar{X}=1.66)$ ile 1-6 yıl arası çalışanlar $(\bar{X}=1.39)$ arasındadır. Ayrıca 25 yıl ve üstü çalışanlar $(\bar{X}=1.66)$ ile 19-24 ( $\bar{X}=1.43)$ yıl arası çalışanlar arasında da anlamlı fark görülmektedir. Buna göre çalışma süresi arttıkça fiziksel geri çekilme davranışlarının görülebildiği söylenebilir.

Tablo 4. Örgütsel Bağlılık, Değişime Direnç ve İşyeri Davranışları ile Kurumda Çalışma Süresine Illişkin ANOVA Sonuçları

\begin{tabular}{|c|c|c|c|c|c|c|c|}
\hline Değişkenler & Gruplar & $\mathbf{N}$ & Ort. & S & $F$ & $p$ & Fark \\
\hline \multirow{5}{*}{$\begin{array}{l}\text { Örgütsel } \\
\text { bağlılık }\end{array}$} & 1. (1-6 y1l) & 87 & 2.82 & 0.64 & \multirow{5}{*}{6.401} & \multirow{5}{*}{$0.000 * * *$} & \multirow{5}{*}{$\begin{array}{c}3-4-5 \text { ve } 1 \\
\text { arasinda }\end{array}$} \\
\hline & 2. (7-12 y1l) & 33 & 2.95 & 0.59 & & & \\
\hline & 3. (13-18 y11) & 32 & 3.34 & 0.77 & & & \\
\hline & 4. (19-24 y11) & 69 & 3.13 & 0.70 & & & \\
\hline & 5. (25 y1l ve üstü) & 38 & 3.30 & 0.48 & & & \\
\hline \multirow{5}{*}{ Duygusal bağlılık } & 1. (1-6 y1l) & 87 & 2.98 & 0.80 & \multirow{5}{*}{4.287} & \multirow{5}{*}{$0.002 * *$} & \multirow{5}{*}{$\begin{array}{c}3-4-5 \text { ve } 1 \\
\text { arasinda }\end{array}$} \\
\hline & 2. (7-12 y11) & 33 & 3.06 & 0.81 & & & \\
\hline & 3. (13-18 y11) & 32 & 3.49 & 0.76 & & & \\
\hline & 4. (19-24 yıl) & 69 & 3.29 & 0.74 & & & \\
\hline & $5 .(25$ yıl ve üstü) & 38 & 3.40 & 0.59 & & & \\
\hline \multirow{5}{*}{ Normatif bağlılık } & 1. (1-6 y1l) & 87 & 2.69 & 0.68 & \multirow{5}{*}{6.405} & \multirow{5}{*}{$0.000 * * *$} & \multirow{5}{*}{$\begin{array}{c}3-4-5 \text { ve } 1 \\
\text { arasinda }\end{array}$} \\
\hline & 2. (7-12 y1l) & 33 & 2.94 & 0.62 & & & \\
\hline & 3. (13-18 y1l) & 32 & 3.28 & 0.90 & & & \\
\hline & 4. (19-24 y11) & 69 & 3.09 & 0.78 & & & \\
\hline & 5. (25 y1l ve üstü) & 38 & 3.23 & 0.61 & & & \\
\hline \multirow{5}{*}{$\begin{array}{l}\text { Devam } \\
\text { bağlılığı }\end{array}$} & 1. (1-6 y1l) & 87 & 2.85 & 0.70 & \multirow{5}{*}{4.873} & \multirow{5}{*}{$0.001^{* *}$} & \multirow{5}{*}{$\begin{array}{l}3-5 \text { ve } 1 \\
\text { arasinda }\end{array}$} \\
\hline & 2. (7-12 y1l) & 33 & 2.85 & 0.53 & & & \\
\hline & 3. (13-18 y1l) & 32 & 3.31 & 0.82 & & & \\
\hline & 4. (19-24 y11) & 69 & 3.03 & 0.79 & & & \\
\hline & $5 .(25$ yıl ve üstü $)$ & 38 & 3.32 & 0.53 & & & \\
\hline \multirow{5}{*}{$\begin{array}{l}\text { Değişime } \\
\text { direnç }\end{array}$} & 1. (1-6 y1l) & 87 & 2.65 & 0.45 & \multirow{5}{*}{3.542} & \multirow{5}{*}{$0.008^{* *}$} & \multirow{5}{*}{$\begin{array}{l}5 \text { ve } 1-2 \\
\text { arasinda }\end{array}$} \\
\hline & 2. (7-12 y1l) & 33 & 2.63 & 0.43 & & & \\
\hline & 3. (13-18 y11) & 32 & 2.79 & 0.56 & & & \\
\hline & 4. (19-24 y11) & 69 & 2.73 & 0.48 & & & \\
\hline & 5. (25 yıl ve üstü) & 38 & 2.97 & 0.49 & & & \\
\hline
\end{tabular}


Tablo 4. Örgütsel Bağlllık, Değişime Direnç ve Isşyeri Davranışları ile Kurumda Çalışma Süresine İlişkin ANOVA Sonuçları (Devamı)

\begin{tabular}{|c|c|c|c|c|c|c|c|}
\hline Değişkenler & Gruplar & $\mathbf{N}$ & Ort. & $\mathbf{S}$ & $F$ & $p$ & Fark \\
\hline & 1. $(1-6$ y1l) & 87 & 3.80 & 0.56 & \multirow{5}{*}{3.403} & \multirow{5}{*}{$0.010^{*}$} & \multirow{5}{*}{$\begin{array}{l}4-5 \text { ve } 1 \\
\text { arasinda }\end{array}$} \\
\hline & 2. (7-12 y11) & 33 & 3.89 & 0.47 & & & \\
\hline \multicolumn{2}{|c|}{ Pozitif iş davranış1 3. (13-18 yıl) } & 32 & 3.97 & 0.65 & & & \\
\hline & 4. (19-24 y1l) & 69 & 4.12 & 0.57 & & & \\
\hline & $5 .(25$ yıl ve üstü $)$ & 38 & 4.03 & 0.54 & & & \\
\hline & 1. (1-6 y1l) & 87 & 2.18 & 0.45 & \multirow{5}{*}{0.884} & \multirow{5}{*}{0.474} & \\
\hline & 2. (7-12 y11) & 33 & 2.07 & 0.53 & & & \\
\hline Psikolojik çekiln & e3. (13-18 y1l) & 32 & 2.11 & 0.58 & & & \\
\hline & 4. (19-24 y1l) & 69 & 2.11 & 0.67 & & & \\
\hline & 5. (25 yıl ve üstü) & 38 & 2.28 & 0.63 & & & \\
\hline \multirow{5}{*}{$\begin{array}{l}\text { Fiziksel } \\
\text { çekilme }\end{array}$} & 1. (1-6 y1l) & 87 & 1.39 & 0.44 & \multirow{5}{*}{2.804} & \multirow{5}{*}{$0.026^{*}$} & \multirow{5}{*}{$\begin{array}{c}3-5 \text { ve } 1 \\
\text { arasinda } \\
5 \text { ve } 4 \\
\text { arasinda }\end{array}$} \\
\hline & 2. (7-12 y11) & 33 & 1.44 & 0.53 & & & \\
\hline & 3. (13-18 y11) & 32 & 1.70 & 0.81 & & & \\
\hline & 4. (19-24 y1l) & 69 & 1.43 & 0.54 & & & \\
\hline & $5 .(25$ yıl ve üstü) & 38 & 1.66 & 0.66 & & & \\
\hline \multirow{5}{*}{$\begin{array}{l}\text { Muhalif } \\
\text { davranışlar }\end{array}$} & 1. (1-6 y1l) & 87 & 2.11 & 0.54 & \multirow{5}{*}{0.613} & \multirow{5}{*}{0.654} & \\
\hline & 2. (7-12 y11) & 33 & 2.19 & 0.58 & & & \\
\hline & 3. (13-18 y1l) & 32 & 2.25 & 0.48 & & & \\
\hline & 4. (19-24 y1l) & 69 & 2.11 & 0.58 & & & \\
\hline & $5 .(25$ y1l ve üstü) & 38 & 2.23 & 0.70 & & & \\
\hline
\end{tabular}

Araştırma değişkenleri arasındaki ilişkileri belirlemek için yapılan korelasyon analizi sonuçları Tablo 5'te verilmiştir. Çalışanların örgütlerine hissettikleri bağlılık ve değişime direnç arasında düşük düzeyde de olsa pozitif ve anlamlı bir ilişki saptanmıştır, $(\mathrm{r}=0.18, p$ $<0.01$ ). Diğer bir ifadeyle çalışanların bağlılık düzeyi arttıkça değişime gösterdikleri direnç de artmaktadır. Örgütsel bağlılığın alt boyutları ile değişime direnç arasındaki ilişkilere bakıldığında; devam bağlılığı ile direnç arasında düşük düzeyde, pozitif ve anlamlı ilişki saptanmıştır, $(\mathrm{r}=0.26, p<0.01)$. Normatif bağlılık ile direnç arasında da düşük düzeyde, pozitif ve anlamlı ilişki tespit edilirken, $(\mathrm{r}=0.18, p<0.01)$ diğer bir alt boyut olan duygusal bağlılık ve direnç arasında istatistiksel olarak anlamlı ilişki yoktur.

Çalışanların örgütsel bağlılık düzeyleri ve işyeri davranışları arasındaki ilişkilere bakıldığında ise, örgütsel bağlılık ve pozitif iş davranışları arasında orta düzeyde, pozitif ve anlamlı ilişki $(r=0.27, p<0.01)$ olduğu görülmektedir. Bağlılık ve psikolojik geri çekilme davranışı arasında ise orta düzeyde, anlamlı negatif ilişki tespit edilmiştir $(r=-0.26, p<0.01)$. Buna göre çalışanların kurumlarına bağlılıkları arttıkça psikolojik geri çekilme davranışlarında azalma görülecektir. Örgütsel bağlılık alt boyutlarının işyeri davranışları ile ilişkilerine bakıldığında; pozitif iş davranışları ile duygusal bağlılık $(\mathrm{r}=0.25, p<0.01)$, devam bağlılı̆̆ $(\mathrm{r}=0.20, p<0.01)$ ve normatif bağlılık $(\mathrm{r}=0.27, p<0.01)$ arasında düşük düzeyde pozitif ve anlamlı ilişki saptanmıştır. Psikolojik geri çekilme ile duygusal bağlılık (r $=-0.32, p<0.01)$, devam bağlılığ $(\mathrm{r}=-0.14, p<0.05)$ ve normatif bağlılık $(\mathrm{r}=-0.23, p<$ $0.01)$ arasında düşük düzeyde negatif anlamlı ilişki vardır.

Son olarak çalışanların değişime gösterdikleri direnç ile işyeri davranışları arasındaki ilişkilere bakıldığında psikolojik geri çekilme $(\mathrm{r}=0.21, p<0.01)$, fiziksel geri çekilme $(\mathrm{r}=$ $0.18, p<0.01)$, ve muhalif iş davranışlarıyla $(\mathrm{r}=0.16, p<0.01)$, düşük düzeyde, pozitif ve anlamlı ilişki saptanmıştır. Değişime direnç ve pozitif iş davranışları arasında anlamlı ilişki yoktur. 
Tablo 5. Değişkenlere İlişkin Korelasyon Katsayıları $(N=259)$

\begin{tabular}{|c|c|c|c|c|c|c|c|c|c|c|c|}
\hline & Ort. & $\mathbf{S}$ & 1 & 2 & 3 & 4 & 5 & 6 & 7 & 8 & 9 \\
\hline $\begin{array}{l}\text { 1. Örgütsel } \\
\text { Bağlılık }\end{array}$ & 3.05 & 0.68 & 1 & & & & & & & & \\
\hline $\begin{array}{l}\text { 2. Duygusal } \\
\text { Bağlılık }\end{array}$ & 3.20 & 0.77 & $0.90 * *$ & 1 & & & & & & & \\
\hline $\begin{array}{l}\text { 3. Devam } \\
\text { Bağlılı̆ğ }\end{array}$ & 3.02 & 0.72 & $0.83^{* *}$ & $0.62 * *$ & 1 & & & & & & \\
\hline $\begin{array}{l}\text { 4. Normatif } \\
\text { Bağlılık }\end{array}$ & 2.98 & 0.75 & $0.95^{* *}$ & $0.80 * *$ & $0.70^{* *}$ & 1 & & & & & \\
\hline $\begin{array}{l}\text { 5. Değişime } \\
\text { Direnç }\end{array}$ & 2.73 & 0.48 & $0.18^{* *}$ & 0.04 & $0.26^{* *}$ & $0.18^{* *}$ & 1 & & & & \\
\hline $\begin{array}{l}\text { 6. Pozitif } \\
\text { Davranışlar }\end{array}$ & 3.95 & 0.57 & $0.27 * *$ & $0.25 * *$ & $0.20 * *$ & $0.27 * *$ & 0.00 & 1 & & & \\
\hline $\begin{array}{l}\text { 7. Psikolojik } \\
\text { Çekilme }\end{array}$ & 2.15 & 0.57 & $-0.26 * *$ & $-0.32 * *$ & $-0.14^{*}$ & $-0.23^{* *}$ & $0.21^{* *}$ & $-0.22 * *$ & 1 & & \\
\hline $\begin{array}{l}\text { 8. Fiziksel } \\
\text { Çekilme }\end{array}$ & 1.48 & 0.57 & 0.02 & -0.04 & 0.05 & 0.03 & $0.18^{* *}$ & $-0.20 * *$ & $0.58^{* *}$ & 1 & \\
\hline $\begin{array}{l}\text { 9. Muhalif } \\
\text { Davranıșlar }\end{array}$ & 2.15 & 0.57 & 0.11 & 0.07 & 0.11 & 0.12 & $0.16^{* *}$ & -0.4 & $0.34 * *$ & $0.43^{* *}$ & 1 \\
\hline
\end{tabular}

Örgütsel bağlılık alt boyutları ve değişime direncin işyeri davranışlarını anlamlı olarak yordayıp yordamadıklarını test etmek için yapılan hiyerarşik regresyon analizi sonuçları Tablo 6'da verilmiştir. Analizde işyeri davranışları olarak ele alınan pozitif davranışlar, psikolojik ve fiziksel geri çekilme ve muhalif davranışlar bağımlı değişken, örgütsel bağlılık alt boyutları ile değişime direnç ise bağımsız değişken olarak ele alınmıştır. VIF değerlerinin 10 'dan düşük olması bağımsız değişkenler arasında çoklu-bağlantılılık sorunu olmadığını göstermektedir (bk. Büyüköztürk, 2012).

Tablo 6. Örgütsel Bağlılık ve Değişime Direncin İşyeri Davranışları Üzerindeki Etkileri

\begin{tabular}{|c|c|c|c|c|c|c|c|}
\hline \multirow[b]{3}{*}{ 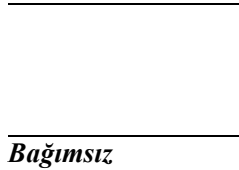 } & \multicolumn{7}{|c|}{ Bă̆ımlı Değişkenler } \\
\hline & \multicolumn{2}{|c|}{$\begin{array}{c}\text { Pozitif } \\
\text { Davranışlar }\end{array}$} & \multicolumn{3}{|c|}{$\begin{array}{c}\text { Psikolojik } \\
\text { Geri Çekilme }\end{array}$} & \multirow{2}{*}{$\begin{array}{c}\text { Fiziksel } \\
\text { Geri } \\
\text { Çekilme } \\
\text { Model } 1 \\
\beta\end{array}$} & \multirow{2}{*}{$\begin{array}{c}\text { Muhalif } \\
\text { Davranışlar } \\
\text { Model } 1 \\
\beta\end{array}$} \\
\hline & $\begin{array}{c}\text { Model } 1 \\
\beta\end{array}$ & VIF & $\begin{array}{c}\text { Model } 1 \\
\beta\end{array}$ & $\begin{array}{c}\text { Model } 2 \\
\beta\end{array}$ & VIF & & \\
\hline Duygusal Bağlılık & 0.09 & 2.89 & $-0.40^{* * *}$ & $-0.33^{* *}$ & 3.02 & - & - \\
\hline Normatif Bağlılık & $0.20 *$ & 3.46 & 0.03 & -0.03 & 3.53 & - & - \\
\hline Devam Bağlılığı & 0.00 & 1.97 & 0.09 & 0.03 & 2.06 & - & - \\
\hline Değişime Direnç & - & & & $0.23 * * *$ & 1.12 & $\underline{0.18 * *}$ & $\underline{0.16 * *}$ \\
\hline$\Delta F$ & 7.07 & & 10.69 & 13.79 & & 8.72 & 6.94 \\
\hline$R^{2}$ (Düzeltilmiş $R^{2}$ ) & $0.08(0.07)$ & & $0.11(0.10)$ & $0.16(0.14)$ & & $0.03(0.03)$ & $0.03(0.02)$ \\
\hline$\Delta R^{2}$ & 0.08 & & & 0.05 & & 0.03 & 0.03 \\
\hline
\end{tabular}

AS2: Örgütsel bağlllık (duygusal, normatif ve devam) ve değişime direnç, pozitif iş davranıslarını anlamlı olarak yordamakta mıdır?

Yapılan korelasyon analizinde pozitif davranış ile duygusal, normatif ve devam bağlılığı arasında düşük düzeyde pozitif korelasyon olduğu saptanırken, değişime direnç ile anlamlı korelasyon tespit edilememişti. Dolayısıyla üç bağlılık türünün pozitif davranışlar üzerindeki etkisini tespit etmek üzere bağlılık alt boyutları tek aşamada regresyona alınmıştır. Modelin $\% 08$ varyans açıkladığı $\left[F_{(3,254)}=7.07, p<0.000\right]$ ve anlamlı olduğu görülmektedir (Tablo 6). $\beta$ katsayıları ve anlamlılık düzeyleri incelendiğinde pozitif davranışlar üzerinde sadece 
normatif bağlılığın etkili olduğu gözlenmiştir. Diğer bağlılık türleri (duygusal bağlılık ve devam bağlılığı) pozitif davranışlara yol açmamaktadır.

AS3: Örgütsel bağlllık (duygusal, normatif ve devam) ve değişime direnç, psikolojik ve fiziksel geri çekilme davranışlarını anlamlı olarak yordamakta mıdır?

Psikolojik geri çekilme davranışları üzerinde bağlılık ve değişime direncin etkisini görmek için yapılan hiyerarşik regresyon analizinin birinci aşamasında bağlılık alt boyutları analize alınmıştır. Modelin \%11 varyans açıkladığı $\left[F_{(3,255)}=10.69, p<0.000\right]$ ve anlamlı olduğu görülmektedir (Tablo 6). $\beta$ katsayıları ve anlamlılık düzeyleri incelendiğinde psikolojik geri çekilme davranışları üzerinde ilk aşamada duygusal bağlılığın negatif yönde etkili olduğu gözlenmiştir. Duygusal açıdan bağlanma azaldıkça, çalışanlarda psikolojik geri çekilme davranışları ortaya çıkmaktadır. Çalışanların normatif ve devam bağlılıkları pozitif ya da negatif yönde psikolojik geri çekilmeyi anlamlı olarak yordamamaktadır. Regresyonun ikinci aşamasında bağlılık alt boyutları ile değişime direnç değişkeni birlikte analize alınmıştır. Model 2'nin psikolojik geri çekilme davranışını açıklama gücü artarak, açıklanan varyansın $\% 16$ 'ya yükseldiği $\left[F_{(1,254)}=13.79, p<0.000\right]$ ve anlamlı olduğu görülmektedir. İkinci modelde duygusal bağlılığın psikolojik geri çekilme davranışını yordayıcılığı düşse de yine en güçlü yordayıcıdır. Normatif ve devam bağlılıkları anlamlı olarak psikolojik geri çekilmeyi yordamamaktadır. Duygusal bağlılığın yordayıcılığı ilk modele göre azalmakla birlikte, değişime direnç değişkeniyle birlikte psikolojik geri çekilme davranışını yordayıcılığı \%05 oranında artmıştır. Buna göre duygusal bağlılığı düşük olan ve değişim karşısında direnç gösteren çalışanlar psikolojik geri çekilme davranışları sergilemektedirler.

Fiziksel geri çekilme davranışları ve bağlılık alt boyutları arasında anlamlı ilişki saptanmamış, değişime direnç değişkeniyle ise düşük düzeyde anlamlı pozitif korelasyon tespit edilmişti. Bu nedenle değişime direnç tek aşamada regresyona alınmıştır. Modelin $\% 03$ varyans açıkladığ $\left[F_{(1,257)}=8.72, p<0.01\right]$ ve anlamlı olduğu görülmektedir (Tablo 6). Bu bulgu değişime direnç gösteren çalışanların fiziksel geri çekilme davranışları sergileyebileceklerini göstermektedir.

\section{AS4: Örgütsel bă̆lllık (duygusal, normatif ve devam) ve değişime direnç, muhalif iş davranışlarını anlamlı olarak yordamakta midır?}

Yapılan korelasyon analizinde muhalif davranışlar ve değişime direnç arasında düşük düzeyde pozitif korelasyon olduğu saptanırken, bağlılık alt boyutları ile anlamlı ilişki tespit edilememişti. Dolayısıyla değişime direncin muhalif davranışlar üzerindeki etkisini saptamak üzere değişime direnç tek aşamada regresyona alınmıştır. Modelin \%03 varyans açıkladığ $1\left[F_{(1,257)}=6.94, p<0.01\right]$ ve anlamlı olduğu görülmektedir (Tablo 6). Buna göre; değişime direnç gösteren çalışanlar muhalif davranışlar sergileyebilmektedirler.

\section{SONUÇ}

Değişim süreçleri, birtakım belirsizlikleri de beraberinde getirdiği için çalışanların konfor alanlarından çıkmalarına ve doğal bir tepki olarak direnç göstermelerine neden olmaktadır. Direnç tepkisi örgütler için olumsuz kabul edilen psikolojik ve fiziksel geri çekilme ve muhalif iş davranışlarıyla sonuçlanabilmektedir. Öte yandan, çalışanların örgütsel bağlılıklarının, özellikle de duygusal ve normatif bağlılıkları yüksek olan çalışanların, değişime dirençle birlikte daha pozitif iş davranışlarına neden olması beklenebilir. Bu varsayımdan hareketle, çalışmada örgütsel bağlılık ve değişime direncin olumlu (pozitif iş davranışları) ve olumsuz işyeri davranışları (psikolojik ve fiziksel geri çekilme ve muhalif iş davranışları) üzerindeki etkileri test edilmiş, ayrıca değişkenlerin demografik özelliklere göre farklılaşıp farklılaşmadığı incelenmiştir. 
Literatürde kadın çalışanların örgütsel bağlılıklarının özellikle de duygusal ve normatif bağlılıklarının daha yüksek olduğuna ilişkin bulgular vardır (Alas, 2009; GenevičiūtèJanonienè ve Endriulaitienè, 2014; Rosenblatt vd., 1999). Erkek çalışanların değişime daha fazla direnç gösterdiklerini ve daha fazla geri çekilme davranışı sergilediklerini saptayan çalışmalar (Genevičiūtè-Janonienè ve Endriulaitienè, 2014) ve değişime direncin cinsiyete göre farklılaşmadığını ifade eden çalışmalar da vardır (Rosenblatt vd., 1999). Bu çalışmada ise bağlılık ve alt boyutları ile değişime dirence ilişkin cinsiyete göre anlamlı fark tespit edilmemiştir. İş davranışlarına ilişkin anlamlı fark sadece pozitif iş davranışlarında (ör. Ekstra işler için gönüllü olma, fazla mesai yapma, iş geliştirme yolları düşünme vb.) tespit edilmiştir. Buna göre; erkek çalışanların daha fazla pozitif iş davranışı sergilediği görülmektedir.

Yine literatürde eğitim düzeyi arttıkça örgüte bağlılığın da arttığ 1 ve değişimin daha olumlu algılandığına ilişkin bulgular vardır (Alas, 2009; Pakdel, 2006). Bu çalışmada ise lise eğitimine sahip çalışanların lisans ve üstü eğitim düzeyine sahip olanlara göre duygusal ve normatif bağlılıklarının daha yüksek olduğu, değişime daha fazla direnç gösterdikleri ve daha fazla fiziksel geri çekilme davranışları sergiledikleri tespit edilmiştir. Bu bulgu literatürle çelişmekle birlikte anlaşılır bir tepki olarak düşünülebilir. Şöyle ki değişimin getirdiği belirsizlik, teknoloji ve yeni uygulamalara uyum sağlamak, eğitim düzeyi görece düşük personel için çok daha zorlayıcı olabilmekte bu da direnç gösterme ve fiziksel geri çekilme olarak ortaya çıkabilmektedir. Ayrıca çalışanların beklentilerinin ve kariyer planlamalarının değişime bakış açılarında birtakım farklılıklara neden olabileceği düşünülmektedir. Eğitim düzeyi görece düşük olan personelin, örgüt içinde yükselme imkanının kısıtlı olması, bu grubun mevcut durumu korumak istemelerine ve örgüte daha fazla bağlilık göstermelerine neden olabilmektedir.

Araştırma değişkenleri kadro pozisyonlarına göre de test edilmiştir. Buna göre; bağlılık düzeyi en düşük unvan grubu icra memurları olarak tespit edilmiştir. İcra memurlarının örgütsel bağlılıklarının düşük olmasının nedenlerinin çalışma koşulları ve görev tanımları bağlamında değerlendirilmesi yerinde olacaktır. Değişim karşısında en çok direnç gösteren grup ise Veri Hazırlama ve Kontrol İşletmenleridir. Örgütsel değişimlere ilişkin uygulamaların çoğunlukla bu grup tarafından yerine getirildiği düşünüldüğünde, değişimin getirdiği belirsizliğin iş yükünü artırmasının bu grupta dirence neden olabileceği söylenebilir. Pozisyona ilişkin işyeri davranışlarına göre anlamlı çıkan fark sadece pozitif iş davranışlarındadır. Yönetici kadrosundaki (müdür, müdür yardımcısı ve şef) personel icra memuru ve denetmenlere göre daha fazla pozitif iş davranışı sergilemektedir. Olumsuz işyeri davranışlarına (geri çekilme ve muhalif davranışlar) ilişkin anlamlı fark tespit edilememiştir.

Yine araştırma bulgularına göre kurumda çalışma süresi 13 yıl ve üzerinde olan çalışanların ilk altı senesindeki çalışanlardan daha fazla örgütlerine bağlı oldukları, 25 yıl ve üstünde kurumda çalışma süresine sahip personelin değişimlere daha fazla direnç gösterdiği, fiziksel geri çekilme ve pozitif iş davranışlarını daha fazla sergiledikleri tespit edilmiştir. Uzun süredir kurumda çalışan personelin alışık oldukları düzenin değişmesi neticesinde daha fazla direnç göstermeleri beklenen bir sonuçtur. Aynı zamanda, yeni iş firsatlarının çoğunlukla azalmış olmasının, bu grubun mevcut durumun devam etmesinden yana tavır almalarına ve dolayısıyla daha fazla bağlılık göstermelerine neden olabileceği söylenebilir.

Değişkenler arası ilişkilere bakıldığında örgütsel bağlılık ve alt boyutları ile pozitif iş davranışları arasında anlamlı pozitif ilişki, psikolojik geri çekilme ile ise anlamlı negatif ilişki olduğu saptanmıştır. Bu bulgu literatürle paralellik göstermektedir. Örgütsel bağlılığın pozitif iş sonuçlarına neden olduğu ve geri çekilme davranışlarını azalttığı literatürde belirtilmektedir (Hanisch ve Hulin, 1991; Meyer vd. 2002). Çalışmada duygusal bağlılık ve değişime direnç arasında anlamlı ilişki bulunmazken, normatif bağlılık ve devam bağlılı̆̆ ile 
değişime direnç arasında pozitif anlamlı ilişki tespit edilmiştir. Buna göre; normatif ve devam bağlılığı yüksek çalışanlar değişime direnç göstermektedirler. Literatürde bağlılık ve değişime direnç arasındaki ilişkilere yönelik farklı bulgular rapor edilmiştir. Sasikala ve Anthonyraj (2015), devam bağlılığ ile ilişki raporlamazken, duygusal ve normatif bağlılık ile değişime direnç arasında negatif ilişki raporlamışlardır. Genevičiūtè-Janonienè ve Endriulaitienè (2014) ise bu çalışmayla paralel olarak duygusal bağlılık ve değişime direnç ile ilişki raporlamazken devam ve normatif bağlılık ile değişime direnç arasında pozitif ilişki saptamışlardır. Değişime direnç ile işyeri davranışları arasındaki ilişkilere bakıldığında pozitif davranışlarla ilişki saptanmazken, psikolojik ve fiziksel geri çekilme davranışları ve muhalif davranışlar ile değişime direnç arasında anlamlı pozitif ilişki bulunmuştur. Değişime direnç gösteren çalışanlar olumsuz işyeri davranışları sergileyebilmektedir. Bu bulgu da literatürle benzerlik göstermektedir (Ör. Peccei vd., 2011; Recardo, 1995).

Çalışmada örgütsel bağlılık ve değişime direncin işyeri davranışları üzerindeki etkileri de test edilmiştir. Pozitif davranışlar ile değişime direnç arasında anlamlı korelasyon tespit edilemediği için bağlılık alt boyutları tek aşamada regresyona alınmış, modelin anlamlı olduğu ancak normatif bağlılığın pozitif davranışları yordadığı, duygusal ve devam bağlılı̆̆ının ise pozitif davranışlara neden olmadığı tespit edilmiştir. Bu bulgu normatif bağlılığı yüksek çalışanların algıladıkları yükümlülükler nedeniyle pozitif iş davranışlarına yöneldikleri şeklinde yorumlanabilir.

Örgütsel bağlılık ve değişime direncin psikolojik geri çekilme davranışları üzerindeki etkisini görmek için ilk modelde bağlılık alt boyutları regresyona alınmış ve duygusal bağlılığın psikolojik geri çekilmeyi negatif yönde yordadığı görülmüştür. Buna göre, duygusal bağlılığı düşük çalışanlar psikolojik geri çekilme davranışları sergileyebilmektedir. $\mathrm{Bu}$ bulgu literatürle paralellik göstermektedir. Örgütsel bağlılı̆̆ın geri çekilme davranışlarını azalttığı, duygusal bağlılığın işe ilişkin çıktılar açısından en olumlu bileşen olduğu literatürde de belirtilmektedir (Ör. Ariani, 2012; Genevičiūtè-Janonienè ve Endriulaitienė, 2014; Meyer vd., 2002). İkinci aşamada değişime direnç değişkeni analize alındığında duygusal bağlılığın yordayıcılığı azalırken modelin anlamlı olduğu görülmektedir. Buna göre, duygusal bağlılığı düşük olan ve değişime direnç gösteren çalışanlar psikolojik geri çekilme davranışı sergileyebilmektedirler. Normatif ve devam bağlılığ yordayıcılar değildir.

Fiziksel geri çekilme ve muhalif iş davranışları ile bağlılık alt boyutları arasında ilişki saptanmadığı için her iki değişken de tek modelde değişime direnç ile regresyona alınmıştır. Her iki modelin de anlamlı olduğu görülmüştür. $\mathrm{Bu}$ bulgu, değişime direnç gösteren çalışanların fiziksel geri çekilme ve muhalif iş davranışları sergileyebildiklerini göstermektedir.

Çalışmanın birtakım sınırlılıkları vardır. Öncelikle çalışma tek bir kamu kurumunda sınırlı örneklem üzerinde test edildiği için verilerin genellenmesi söz konusu değildir. Ayrıca ele alınan değişkenler, özellikle geri çekilme ve muhalif iş davranışları ölçekleri maddeleri itibariyle çalışanların gerçek düşüncelerini yansıtmaktan çekinmelerine ve sosyal arzu edilebilirlik etkisinde anketi yanıtlamalarına neden olmuş olabilir. $\mathrm{Bu}$ da gerçek etkilerin ortaya çıkarılmasını zorlaştırmaktadır. Belirtilen sınırlılıklara rağmen çalışma, örgütsel bağlılık ve değişime direncin etkilerinin olumlu ve olumsuz işyeri davranışlarına etkilerinin aynı örneklem grubunda test edilmesi nedeniyle önemli görülmektedir. Çalışma bulguları değişime direnci en aza indirmek ve olumsuz işyeri davranışlarından kaçınmak isteyen yöneticiler ve insan kaynakları uzmanları için yol gösterici nitelikte olabilir. Son olarak çalışmada kesitsel araştırma deseni kullanılmıştır. Bağlılık ve değişime direncin işyeri davranışları üzerindeki etkilerinin yapılacak boylamsal çalışmayla değişim uygulamaları öncesinde ve sonrasında test edilmesi önerilebilir. 


\section{Kaynakça}

Alas, R. (2009). The Impact of Work-Related Values on the Readiness to Change in Estonian Organizations. Journal of Business Ethics. 86. 113-124. doi: 10.1007/s10551-008-9838-5

Allen, N. J. ve Meyer, J. P. (1990). The Measurement and Antecedents of Affective. Continuance and Normative Commitment to the Organization. Journal of Occupational Psychology. 63. 1-18.

Allen, N. J. ve Meyer J. P. (1996). Affective, Continuance and Normative Commitment to the Organization: An Eexamination of Construct Validity. Journal of Vocational Behavior. 49(3). 252-276.

Altındiş, M., Altındiş, S. ve Saylı, H. (2011). Sağlık Profesyonellerinin Değişim Sürecindeki Tutumlarını Belirlemeye Yönelik Bir Araştırma. ZKÜ Sosyal Bilimler Dergisi. 7(14). 75-93.

Arıkan, E. (2011). The Relationship Between Organizational Citizenship Behavior, Organizational Culture, and Organizational Commitment. (Yayımlanmamış Yüksek Lisans Tezi). Orta Doğu Teknik Üniversitesi. İşletme Bölümü. Ankara.

Ariani, D. W. (2012). Leader-Member Exchanges as a Mediator of the Effect of Job Satisfaction on Affective Organizational Commitment: An Empirical Test. International Journal of Management. 29(1). 46-56.

Armenakis, A. A. ve Bedeian, A. G. (1999). Organizational Change: A Review of Theory and Research in the 1990s. Journal of Management. 25(3). 293-315.

Ayden, C. ve Y1lmaz, İ. (2018). Organizasyonlarda Değişim ve Değişime Karşı Direncin Örgütsel Adalet ve Değişime Bağlllık Boyutları ile İncelenmesi: Frrat Üniversitesi İdari Çalışanları Üzerine Bir Araştırma. Turkish Studies. 13(7). 339-366. doi: 10.7827/Turkish Studies.13101

Baysal, C., Mısırdalı Yangil, F. ve Sevim, Ş. (2020). Analysis of the Relationship between Organizational Commitment and Counter Productive Work Behaviour on Academicians. Serbian Journal of Management. 15(1). 143157. doi:10.5937/sjm15-18502

Becker, H. S. (1960). Notes on the Concept of Commitment. American Journal of Sociology. 66(1). 32-40.
Bellou, V. (2008). Exploring Civic Virtue and Turnover Intention During Organizational Changes. Journal of Business Research. 61(7). 778-789. doi: 10.1016/j.jbusres.2007.09.001

Buchanan, B. (1974). Building Organizational Commitment: The Socialization of Managers in Work Organizations. Administrative Science Quarterly. 19(4). 533-546.

Büyüköztürk, Ş. (2012). Sosyal Bilimler için Veri Analizi El Kitabı Istatistik, Araştırma Deseni SPSS Uygulamalarl ve Yorum. Ankara: Pegem Akademi Yayıncilık.

Chawla, A. ve Kelloway, E. K. (2004). Predicting Openness and Commitment to Change. The Leadership \& Organization Development Journal. 25(6). 485-498. doi: 10.1108/01437730410556734

Chiang, C. F. (2010). Perceived Organizational Change in the Hotel Industry: An Implication of Change Schema. International Journal of Hospitality Management. 29(1). 157-167. doi: 10.1016/j.ijhm.2009.08.002

Chreim, S. (2008). Managerial Frames and Institutional Discourses of Change: Employee Appropriation and Resistance. Organization Studies. 27(9). 1261-1287. doi: 10.1177/0170840606064106

Clegg, C. W. (1983). Psychology of Employee Lateness Absence and Turnover: A Methodological Critique and Empirical Study. Journal of Applied Psychology. 68(1). 88-101.

Coch, L. ve French, J. R. P. (1948). Overcoming Resistance to Change. Human Relations. 1(4). 512-532.

Eder, P. ve Eisenberger, R. (2008). Perceived Organizational Support: Reducing the Negative Influence of Coworker Withdrawal Behavior. Journal of Management. 34(1). 55-68. doi: 10.1177/0149206307309259

Elias, S. M. (2009). Employee Commitment in Times of Change: Assessing the Importance of Attitudes Toward Organizational Change. Journal of Management. 35(1). 37-55. doi: 10.1177/0149206307308910

Erdemli, Ö. (2015). Teachers Withdrawal Behaviors and Their Relationship with Work Ethic. Eurasian Journal of Educational Research. 15(60). 201-220. doi: 10.14689/ ejer.2015.60.12 
Falkenburg, K. ve Schyns, B. (2007). Work Satisfaction, Organizational Commitment and Withdrawal Behaviours. Management Research News. 30(10). 708-723. doi: 10.1108/01409170 710823430

Foster, R. D. (2010). Resistance, Justice and Commitment to Change. Human Resource Development Quarterly. 21(1). 3-38. doi: 10.1002/hrdq.20035

Genevičiūtè-Janonienè, G. ve Endriulaitienė, A. (2014). Employees Organizational Commitment: Its Negative Aspects For Organizations. Procedia- Social and Behavioral Sciences. 140.558 - 564 . doi: 10.1016/j.sbspro.2014.04.470

Giangreco, A. ve Peccei, R. (2005). The Nature and Antecedents of Middle Manager Resistance to Change: Evidence from an Italian Context. The International Journal of Human Resource Management. 16(10). 1812-1829. doi: $10.1080 / 09585190500298404$

Gonçalves, J. M. ve da Silva Gonçalves, R. P. (2012). Overcoming Resistance to Changes in Information Technology Organizations. Procedia Technology. 5. 293-301. doi: 10.1016/j.protcy.2012.09.032

Grama, B. ve Todericiu, R. (2016). Change, Resistance to Change and Organizational Cynicism. Studies in Business and Economics. 11(3). 47-54. doi: 10.1515/sbe-2016-0034

Hanisch, K. A. ve Hulin, C. L. (1991). General Attitudes and Organizational Withdrawal: An Evaluation of a Causal Model. Journal of Vocational Behavior.39(1). 110-128. doi: 10.1016/0001-8791(91)90006-8

Herscovitch, L. ve Meyer, J. P. (2002). Commitment to Organizational Change: Extension of a Three-Component Model. Journal of Applied Psychology. 87(3). 474-487. doi:10.1037//0021-9010.87.3.474

Idris, M. K., O’Driscoll, M. P. ve Anderson, M. H. (2011). Longitudinal Mediation Effects of Strain on the Relationships Between Role Stressors and Employees' Withdrawal Rresponses. Stress and Health. 27(5).403-412.

Iverson, R. D. (1996). Employee Acceptance of Organizational Change: The Role of Organizational Commitment. The International Journal of Human Resource Management. 7(1). 122-149.
Kanter, R. M. (1968). Commitment and Social Organization: A study of Commitment Mechanisms in Utopian Communities. American Sociological Review. 33(4). 499-517.

Karasar, N. (2009). Bilimsel Araştırma Yöntemi. (19. Bask1). Ankara: Nobel Yayın Dağıtım.

Kılıç, S. (2016). Cronbach'ın Alfa Güvenirlik Katsayıs1. Journal of Mood Disorders. 6(1). 4748. doi: 10.5455/jmood.20160307122823

Klein, K. J. ve Sorra, J. S. (1996). The Challenge of Innovation Implementation. Academy of Management Review. 21(4). 1055-1080.

Kotter, J. P. (1995). Leading Change: Why Transformation Efforts fail. Harvard Business Review. March-April. 59-67.

Kotter, J. P. ve Schlesinger, L. A. (1979). Choosing Strategies for Change. Harvard Business Review. 57(2). 106-114.

Lam, L. W. ve Liu, Y. (2014). The IdentityBased Explanation of Affective Commitment. Journal of Managerial Psychology. 29(3). 321340. doi: 10.1108/JMP-02-2012-0036

Lehman, W. E. K. ve Simpson, D. D. (1992). Employee Substance use and on-the Job Behaviors. Journal of Applied Psychology. 77(3). 309-321

Lines, R. (2005). The Structure and Function of Attitudes Toward Organizational Change. Human Resource Development Review. 4(1). 832. doi: $10.1177 / 1534484304273818$

Luchak, A. A. ve Gellatly, I. R. (2007). A Comparison of Linear and Nonlinear Relations Between Organizational Ccommitment and Work Outcomes. Journal of Applied Psychology. 92(3). 786-793. doi: 10.1037/00219010.92.3.786

Mangundjaya, W. L. H., Utoyo, D. B. ve Wulandari, P. (2015). The Role of Leadership and Employee's Condition on Reaction to Organizational Change. Procedia- Social and Behavioral Sciences. 172. 471 - 478. doi: 10.1016/j.sbspro.2015.01.385

McKay, K. Kuntz, J. R. C. ve Näswall, K. (2013). The Effect of Affective Commitment. Communication and Participation on Resistance to Change: The Role of Change Readiness. New Zealand Journal of Psychology. 42(2). 29-40. 

Muhalif İş Davranışları Üzerindeki Etkileri

Meyer, J. P. ve Allen, N. J. (1984). Testing the "Side-Bet Theory" of Organizational Commitment: Some Methodological Considerations. Journal of Applied Psychology. 69(3). 372-378.

Meyer, J. P. ve Allen, N. J. (1991). A ThreeComponent Conceptualization of Organizational Commitment. Human Resource Management Review. 1(1). 61-89.

Meyer, J. P. ve Allen, N. J. (1997). Commitment in the Workplace: Theory, Research and Application. Thousand Oaks, CA: Sage.

Meyer, J. P. ve Allen, N. J. (2004). TCM Employee Commitment Survey Academic Users Guide 2004. The University of Western Ontario.

Meyer, J. P., Hecht, T. D., Gill, H. ve Toplonytsky, L. (2010). Person-Organization (culture) Fit and Employee Commitment Under Conditions of Organizational Change: A Longitudinal Study. Journal of Vocational Behavior. 76(3). 458-473. doi: 10.1016/j.jvb.2010.01.001

Meyer, J. P., Stanley, D. J., Herscovitch, L. ve Topolnytsky, L. (2002). Affective, Continuance and Normative Commitment to the Organization: A Meta-Analysis of Antecedents, Correlates and Consequences. Journal of Vocational Behavior. 61(1). 20-52. doi: 10.1006/jvbe.2001.1842

Ming-Chu, Y. ve Meng-Hsiu, L. (2015). Unlocking the Black Box: Exploring the Link Between Perceive Organizational Support and Resistance to Change. Asia Pacific Management Review. 20(3). 177-183. doi:10.1016/j.apmrv. 2014.10.003

Okumus, F. ve Hemmington, N. (1998). Barriers and Resistance to Change in Hotel Firms: An Investigation at Unit Level. International Journal of Contemporary Hospitality Management. 10(7). 283-288.

Oreg, S. (2003). Resistance to Change: Developing an Individual Differences Measure. Journal of Applied Psychology. 88(4). 680-693. doi: 10.1037/0021-9010.88.4.680

O’Reilly, C. ve Chatman, J. (1986). Organizational Commitment and Psychological Attachment: The Effects of Compliance. Identification and Internalization on Prosocial Behavior. Journal of Applied Psychology. 71(3). 492-499.
Örücü, E. ve Kambur, E. (2019). Beş Yıldızlı Otel İşletmesinde Örgütsel Güvenin Değişime Direnç Üzerindeki Etkisi: Bir Alan Araştırması. Doğuş Üniversitesi Dergisi. 20(2). 105- 118.

Pakdel, A. (2016). An Investigation of the Difference in the Impact of Demographic Variables on Employees' Resistance to Organizational Change in Government Organizations of Khorasan Razavi. ProcediaSocial and Behavioral Sciences. 230. 439-446. doi: 10.1016/j.sbspro.2016.09.055

Paolillo, A., Platania, S., Magnano, P. ve Ramaci, T. (2015). Organizational Justice, Optimism and Commitment to Cchange. Procedia- Social and Behavioral Sciences. 191. 1697 - 1701. doi:10.1016/j.sbspro.2015.04.479

Peccei, R. Giangreco, A. ve Sebastiano, A. (2011). The Role of Organisational Commitment in the Analysis of Rresistance to Change CoPredictor and Moderator Effects. Personnel Review. 40(2). 185-204. doi:10.1108/00483 481111106075

Piderit, S. K. (2000). Rethinking Resistance and Recognizing Ambivalence: A Multidimensional View of Attitudes Toward an Organizational Change. Academy of Management Review. 25(4). 783-794.

Porter, L. W., Steers, R. M., Mowday, R. T. ve Boulian, P. V. (1974). Organizational Commitment, Job Satisfaction and Turnover Among Psychiatric Technicians. Journal of Applied Psychology. 59(5). 603-609.

Qazi, S., Naseer, S. ve Syed, F. (2019). Can Emotional Bonding Be A Liability? Status Striving as an intervening Mechanism in Affective Commitment and Negative Work Behaviors Relationship. Revue Européenne de Psychologie Appliquée. 69(4). 1-11. doi: 10.1016/j.erap.2019.100473

Recardo, R. J. (1995). Overcoming Resistance to Change. National Productivity Review. (Spring). 5-12.

Rosenblatt, Z., Talmud, I. ve Ruvio, A. (1999). A Gender-Based Framework of the Experience of Job Insecurity and its Effects on Work Attitudes. European Journal of Work and Organizational Psychology. 8(2). 197-217. doi: 10.1080/135943299398320 
Rosse, J. G. ve Hulin, C. L. (1985). Adaptation to Work: An Analysis of Employee Health, Withdrawal and Change. Organizational Behavior and Human Decision Processes. 36(3). 324-347.

Sasikala, S. ve Anthonyraj, S. V. (2015). SelfEfficacy. Emotional Intelligence and Organizational Commitment in Relation to Resistance to Change Among Employees. AIJBSR (SPECIAL ISSUE). 30. 30-35.

Smollan, R. K. (2006). Minds, Hearts and Deeds: Cognitive, Affective and Behavioural Responses to Change, Journal of Change Management. 6(2). 143-158. doi: 10.1080/ 14697010600725400

Somers, M. J. (2009). The Combined Influence of Affective, Continuance and Normative Commitment on Employee Withdrawal. Journal of Vocational Behavior. 74(1). 75-81. doi: 10.1016/j.jvb.2008.10.006

Tavakoli, M. (2010). A Positive Approach to Stress, Resistance and Organizational Change. Procedia Social and Behavioral Sciences. 5. 1794-1798. doi: 10.1016/j.sbspro.2010.07.366

Wasti, S. A. (2005). Commitment Profiles: Combinations of Organizational Commitment Forms and Job Outcomes. Journal of Vocational Behavior. 67(2). 290-308. doi: 10.1016/j.jvb.2004.07.002

Wiener, Y. (1982). Commitment in Organizations: A Normative View. Academy of Management Review. 7(3) 418-428. 